\title{
The Comparative Study and Designing of a Conceptual Model for Media Literacy Based on the Evolutional Documents of Iranian Education
}

\begin{abstract}
- Zahra Nurani ${ }^{1} \quad$-Sayyid Bashir Husseini ${ }^{2} \quad$ = Akram Gudarzi ${ }^{3} \quad$-Susan Keshavarz ${ }^{4}$
- Objective: This study aimed at designing a native-Islamic model of media literacy based on the evolutional documents of education in the formal and public education system of Iran in $1399 \mathrm{SH}$.

- Method: Using the library and documentary study method in qualitative research methods, a comparative study of the experiences of leading countries in the field of media literacy, and an analytical study of educational documents of education were conducted. The research population included documents and information on media literacy in the three leading countries of Canada, Japan, and Australia, as well as the educational evolution documents including the document of the theoretical foundations of fundamental change, the document of a fundamental change of education, and other supporting documents including documentation of space supply subsystems, equipment and technology, national curriculum, financial resources, research, guidance and management, and teacher training. This study used the purposive sampling method and to analyze the information, comparative study methods and inductive content analysis were used.
\end{abstract}

- Findings: The research findings indicate the conceptualization of media literacy in redefining all dimensions (principles, definition, characteristics, approach, and perspective). Accordingly, the model of media literacy was designed on the basis of the values and foundations of monotheistic worldview, with an emphasis on the position of the divine caliph, rationalism, responsibility, acquiring knowledge, limitation of cognition, emphasis on purified life (based on individual and collective growth), hierarchical nature of purified life, educational justice, emphasis on benefaction and forgiveness, emphasis on promoting the aesthetic dimension in all components. One of the most important features of this model is the approach and perspective of "Position recognition and improving position in the media space" and "continuous development and excellence of learners' media identity", which has not been considered in other models of media literacy.

- Conclusion: Therefore, by designing such a conceptual model, all media literacy processes in the country find a native-Islamic direction and get rid of fragmentation and confusion.

\section{Keywords: Native-Islamic model, Comparative study, Educational transformation} documents, Media literacy, Media identity

- Citation: Citation: Zahra Nurani,Sayyid Bashir Husseini,, Akram Gudarzi\& Susan Keshavarz.(2021). The Comparative Study and Designing of a Conceptual Model for Media Literacy Based on the Evolutional Documents of Iranian Education, Applied Issues in Islamic education, 6(2):133-164.

Received: $2020 / 09 / 22$

Accepted: 2021/07/01

1. A Ph.D. Student of Educational Management, Imam Sadiq University, Females' Campus, Tehran, Iran. E-mail: yas1367no@yahoo.comm. iD 0000-0001-9873-4827.

2. Corresponding Author: An Assistant Professor in Faculty of Communications and Media, University of IRIB, Tehran, Iran.

E-mail: saiedbashir@gmail.com. (D) 0000-0003-2396-6396

3. An Assistant Professor in Faculty of Knowledge and Educational Sciences, Imam Sadeq University, Females' Campus, Tehran, Iran.

E-mail: goodarzi@isuw.ac.ir. (D) 0000-0002-3872_0180.

4. An Associate Professor in Faculty of Psychology and Educational Sciences, Kharazmi University, Tehran, Iran. E-mail: ss.keshavarz@yahoo.com. (iD orcid.org/0000-0002-7709-2500. 



\section{مطالعه تطبيقى وطراحىى

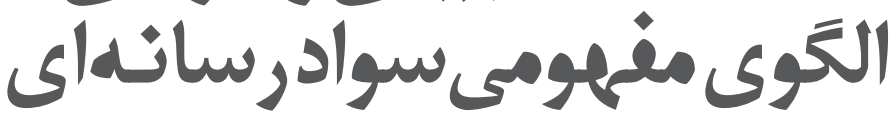

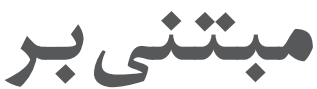

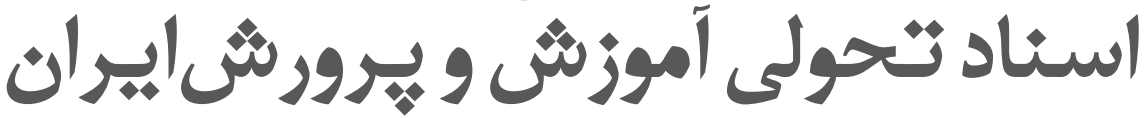

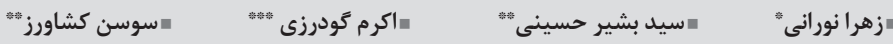

\section{هُم}

ه هدف: يزوهش حاضر با هدف طراحى الكوى بومى ـ اسلامىسواد رسانهاى مبتنى بر اسناد

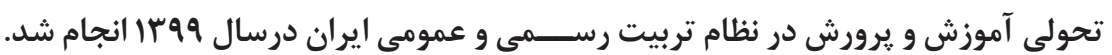

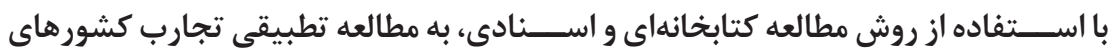

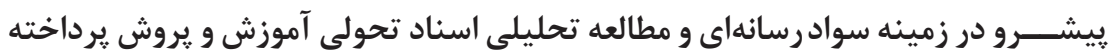

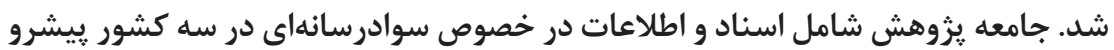

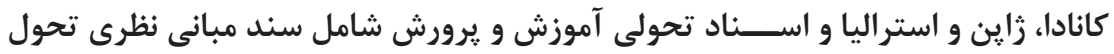

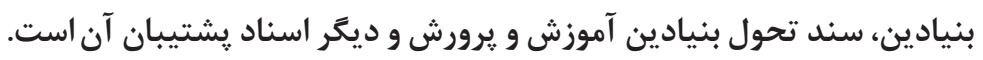

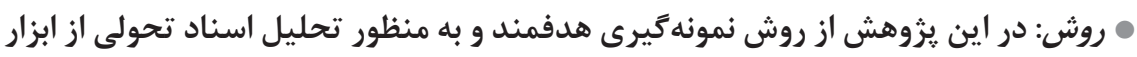
تحليل محتواى كيفىاستقرايى تا سطح كدكذارى باز استفاده شد دون

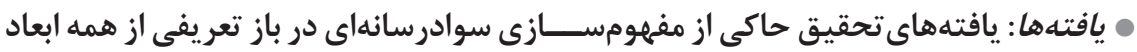

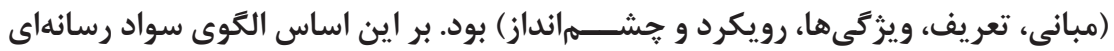

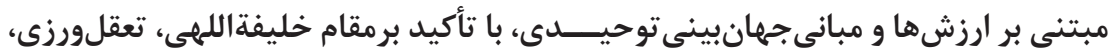

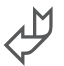

E-mail: yas1367no@yahoo.com. (iD) 0000-0001-9873-4827

\section{* دانشجو دكترى رشته مديريت آموزشى، دانشعاه امام صادق(ع) تيرديس خواهران، تهران، ايران.} ** نويسنده مسئول: استاديار دانشكده ارتباطات و رسانه، دانشعاه صدا و سيما، تهران، ايران. E-mail: saiedbashir@gmail.com. (D) 0000-0003-2396-6396

**** استاديار دانشكده معارف و علوم تربيتى، دانشگاه امام صادق(ع) برديس خواهران، تهران، ايران. E-mail: goodarzi@isuw.ac.ir. (iD) 0000-0002-3872_0180 
مســــؤليت يذيرى، معرفتيابى، محدوديت شناخت، تأكيد برحيات طيبه (مبتنى بر رشد

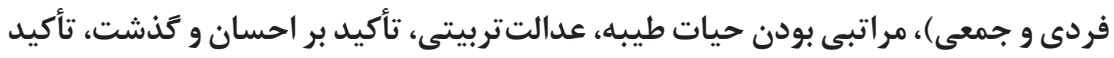

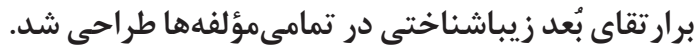

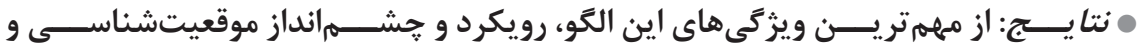
موقعيت آفرينى در فضاى رسانهاى و تكوين و تعالى ييوسته هويت رسانهاى متربيان است.

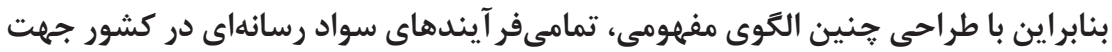

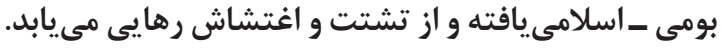

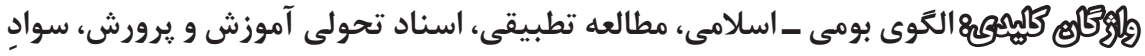
رسانهاى، هويتِ رسانهاى

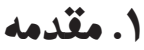

نظام نو يديد جهانى، آميخته با انواع رســانهها اســـ؛ عصرى كه در آن رسانههاى گروهـــى جزء جدايى نايذير زندگى هســتند و هر روز تغييرات زيرشــاب درعرصههاى

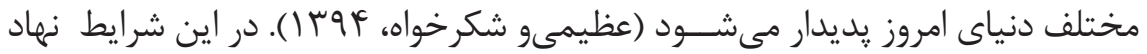
آموزش و گيرورش نيازمند توجهى دوصد جندان است تا بتواند وظايف اساسى خود را در برابر نســل فرداى كشور بهَّونهاى بايسته انجام دهد. امروزه از رسانهها در كنار خانواده و مدرســهـ بهعنوان مربيان فعال نام برده مىشـــود و حتى فراتر از آن، به برهم خوردن

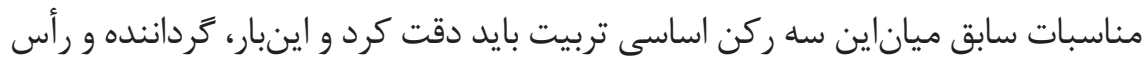

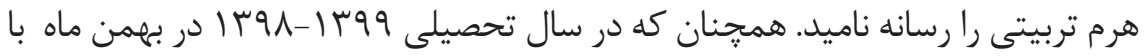
روند شــيوع بيمارى كرونا در جهان از جمله ايران، مدرسه و اهداف آن به روش آموزش تلويزيونى و مدرسه شــاد در قالب آموزش الكترونيكى مصداق ييدا كرد، واقعيتى كه از تهديد كرونا در جامعه آموزشى ايران فرصتها را رقمم زد. يزوهش ها ييش از شيوع كرونا نشان مىداد كه بهطور ميانخين، نزديك به • V درصد از زمان روزانه افراد، به نوعى استفاده از رسانه را شامل مىشود (يزديان، ( وس )). درحالى كه آمار و ارقام استفاده از اينترنت در ايران همعام با جهان، هر روز افزايش مىيابد. بر اساس

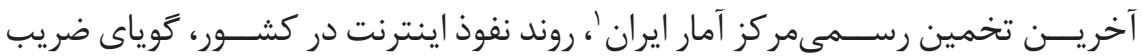


مطالعه تطبيقى وطراحى الكَى مفهومى سواد رسانهاى

مبتنى بر اسناد تحولى آموزش و يروريقي مفروايران

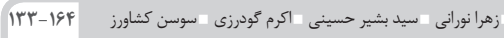

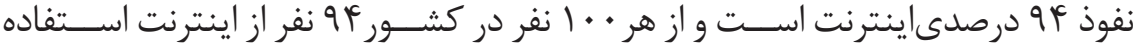

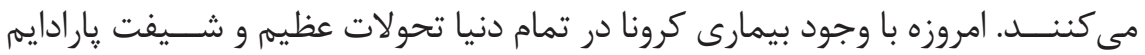

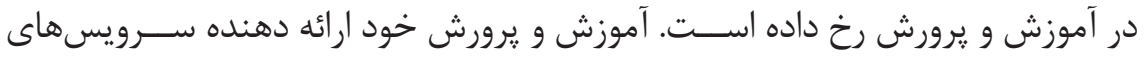

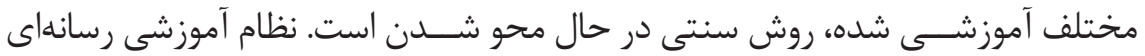

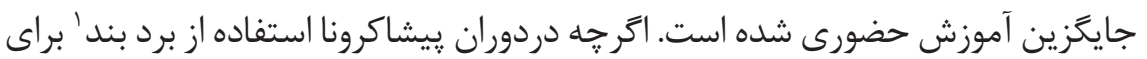

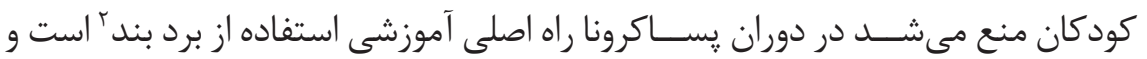

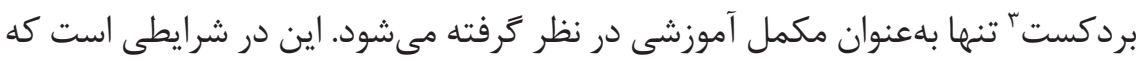

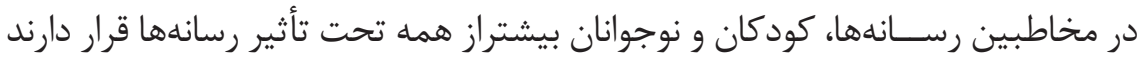

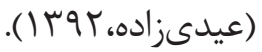

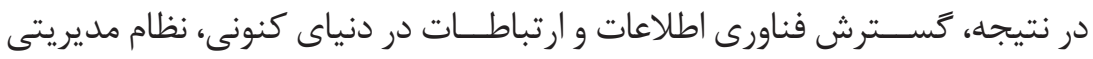

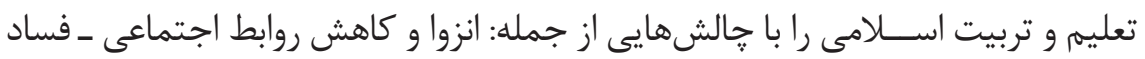

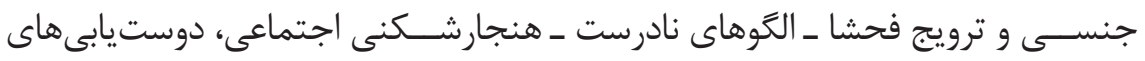

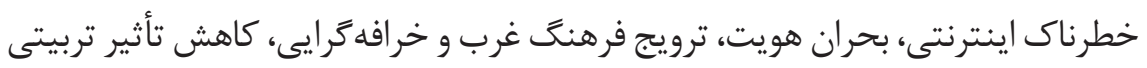

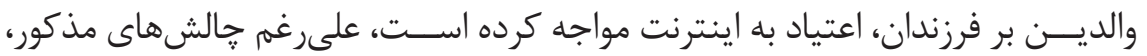

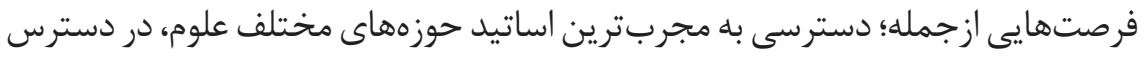

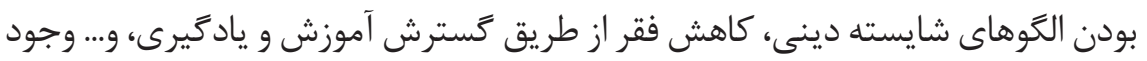
دارد (بليدئى، سو باى (). با توجه به رشد شتابان فناورىهاى نوين، اقتضاى دوران يساكروناو عدم توان كنترل

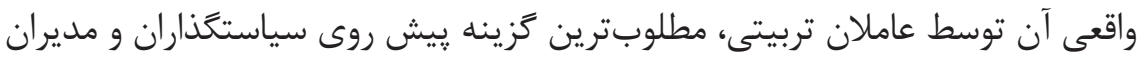

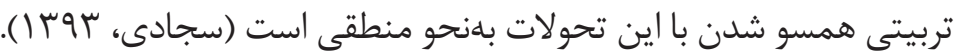

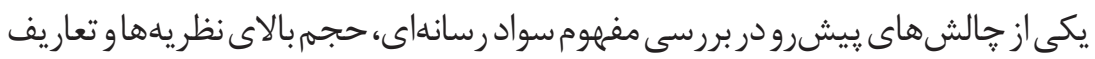

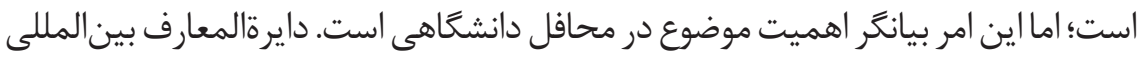

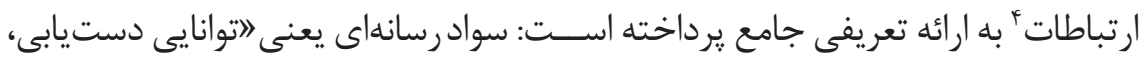
تحليل، ارزيابى و خلق بيامهايى در زمينههــاى مختلفه (Donsbach, 2008:2926).

1. Boardband

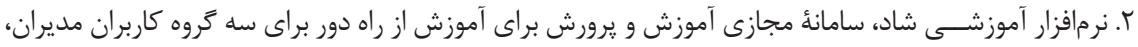

4. The international Encyclopedia of communication

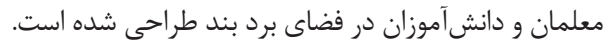


از نظر انجمن ملى آموزش سواد رسانهاى آمريكا' سواد رسانهاى، توانايى دسترسى، تجزيه و تحليل، ارزشـــابى و توليد و برخورد فعال با ريام در انواع مختلف رســانههاى ارتباطى اســت كه به افراد در تبديل شــدن به متفكرانى نقاد و خلاق و شهروندانى فعال كمكى رك مى كند (NAMLE, 2020). لذا اين تعريف جامع، اساســى براى :يشـــبرد اهداف سواد رسانهاى در رويكردهاى مختلف جهانى است. ذكراين مطلب ضرورى اســت وازه لاتيـن 》ycaretiL aideM) در ادبيات جهانى، با دو رويكرد مفهومى مورد ملاحظه قرار گرفته اســت. در برخى مواقع با رويكرد عام و

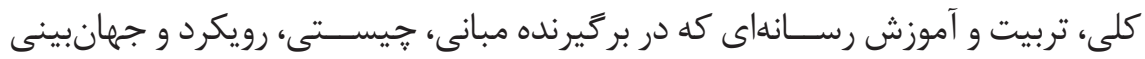
ســـواد رسانهاى مبتنى بر نغاههاى فلسفى است و در برخى مواقع با رويكرد خاص، صرفاً بر آموزش رسانهاى بهمعناى نحوه و جُخونگَى ياددهى سواد رسانهاى دلالت دارد. در اين يزوهش سواد رسانهاى به مفهوم عام، اعم از تربيت و آموزش رسانهاى مد نظر است. يونسكوّ، از دهاى •9919 در راستاى توسعه آموزش سواد رسانهاى برنامههاى جهانى اجرا نموده اســت(محمودى كوكنده، •وس ( ). كانادا اولين كشور است كه سواد رسانهاى را در برنامهدرســى مدارسايالت انتاريوّى خود الزامى كـــــ. از جمله نهادهاى فعال در حوزه سواد رسانهاى در كشــور كانادا مىتوان به 》انجمن سواد رسانهاى « اشاره نمود و مهممترين دستاورد آن گَنجاندن سواد رسانهاى در برنامهدرسى مدارس استان انتاريو بود. كانادا كشورى اســت كه افراد با پيشيشههاى قومى و زبانى بسيار متفاوت در آن زندگى مى كنند؛ درنتيجه يك يار جه كردن قوميّتهاى مختلف براى دولت آن، همواره از ضروريات

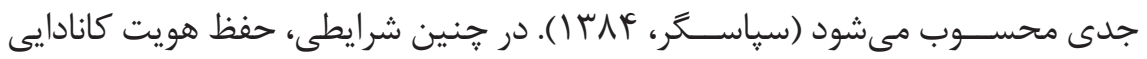
و يكـيار:جــه كردن قوميتها براى اين كشـــور ضرورت يافته اســت (Valskvi, 2005). ضرورت آموزش سواد رسانهاى در زاين، نخستين بار در دهه •^ از سوى وزارت يست و

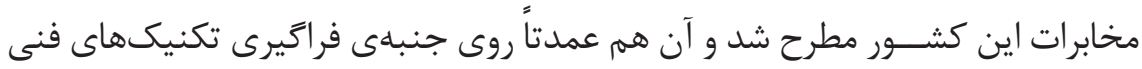
رســانهاى متمركز بود. با وجود اين، تمركز بهسوى رويكردى حركت كرد كه اكنون در زاين، سواد رسانهاى، در حوزهاى وســيعتر آموزش داده مىشود كه از زيرمجموعههاى

1. National American Media Litteracy Education

2. Unesco

3. Ontario

4. Association for Media Literacy(AML) 
مطالعه تطبيقى وطراحى الكوى مفهومى سواد رسانهاى

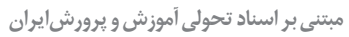

زهرانورانى سيد بشير حسينى اكرم كودرزى سوسن كثاورز

آن علاوه بر فراگيرى تكنيكهاى فنى رسانهاى، آموزش توليدات رسانهاى است. باگذشت

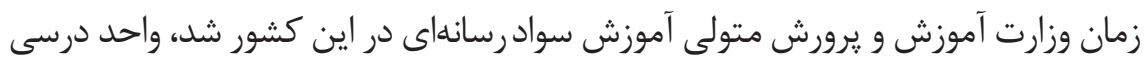
اسواد رسانهاى" را باعنوان يك واحد درسى اختيارى در نظام آموزشى لحاظ نمود (نصيرى

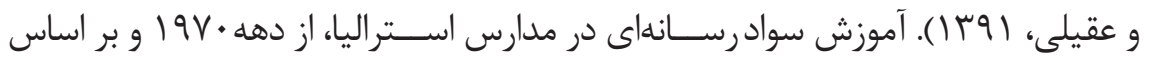
ديد أهى تركيبى در قبال فعاليتهاى تحصيلى با ســاله دوران قبل از دانشـــاه مطرح شـــد. از ميانه دهه • 199 به بعد، اســـتراليا آموزش سواد رسانهاى را از مهرد كودى تا سال دوازدهم تحصيل اجبارى نمود. اين برنامه تحصيلى بر جنبههاى زيبايىشــناختى و زبان شـــناختى تأكيد و رويكردى آزاد نسبت به هنرهاى عامهِيسند اختيار مى كند. بسيارى از فعاليتهاى آموزش رسانهاى فعلى درايالات متحده، از نظامآموزشى استراليا اقتباس شده اســت (Hobbs, 1998). با توجه به قدمت كم سواد رســانهاى در كشور ايران، همجنان از

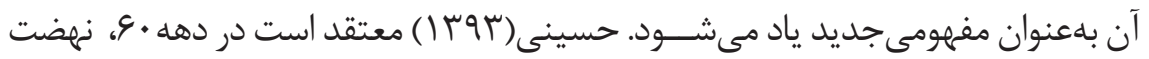
هم乏انى "اسواد آموزى" در ايران بنا شد، در دهه • 9 بايد "انهضت سواد رسانهاى" با ابعادى وسيع و ملى صورت يذيرد و در موجى از يايين به بالا (اقدامات فعالانه بخش خصوصى) و حمايتى از بالا به يايين (همراهى نهادهاى عمومى و دولتى)، اين نهضت محقق شود. تاكنون :زروهش هاى بينالمللى و داخلى بسيارى در زمينه سواد رسانهاى انجام شده

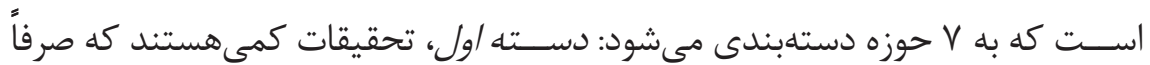
به ســـنجش ميزان سواد رسانهاى و بررســى عوامل مؤثر بر افزايش سطح آن مىيردازند

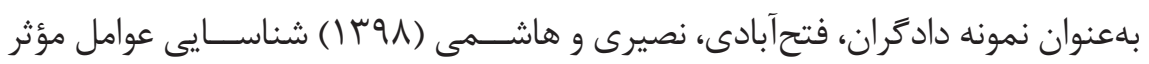

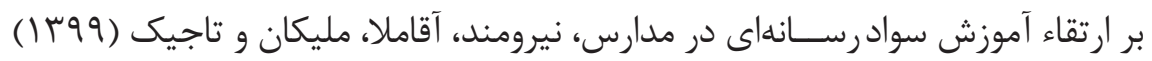
بررســى اثر سواد رسانهاى در مهارتهاى زندگىى؛ دســـه دوم، تحقيقاتى هستند كه به

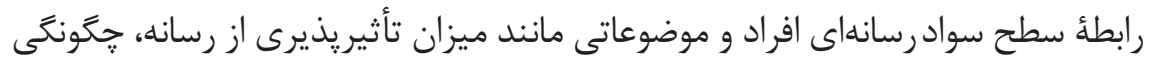

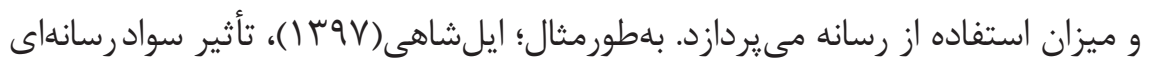

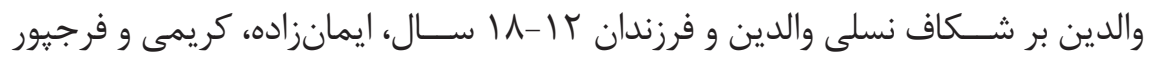
بناب (1) (1)، اثربخشى آموزش سواد رسانهاى بر كاهش اضطراب اطلاعاتى دانشجويان

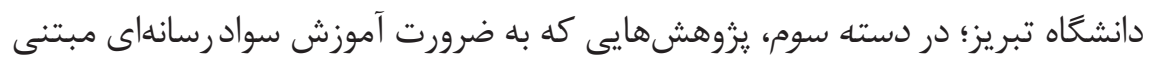
بر اســناد بالادستى در نظام آموزش و يرورش، آموزش عالى، صدا و سيما يرداختهاند از

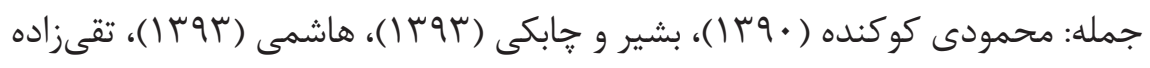




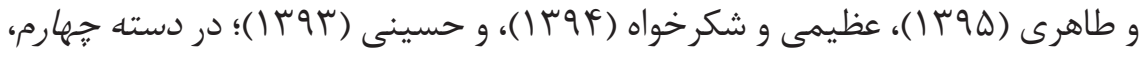
بســيارى از محققين به بيان تجربيات خود در خصوص روشها و برنامههاى درسـىى

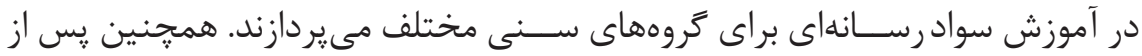
ورود كتاب اتفكر و سواد رســانهاى" به برنامه درســى يايه دهم نظام آموزشى كشور از ســال هوسا ، بخشى از يثوهشها به نقد و ارزيابى اين كتاب و يا اثربخشى تدريس

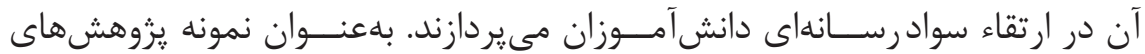

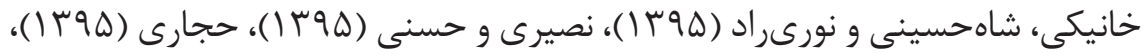
Daunic(2011), Martens (2010) ،Wood(2009) ‘Friedman McDonald(2008) Wilson- Grizzle - Tuazon - Akyempong \& Cheung (2011), (Malhan \& Singh (2016) Hobbs, Felini, Cappello(2011), Murakami(2016)

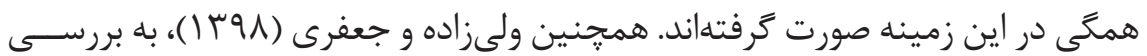
نقش كتاب تفكر و سواد رسانهاى در ارتقاى ابعاد جهار گانه (شناختى، احساسى، زيبايى شناختى و اخلاقى) سواد رسانهاى دانشآموزان مدارس متوسطه دوره دوم شهر اردبيل يرداختهاند. يافتههاى يزوهش نشــان داده است كهاين كتاب در ارتقاى سوادرسانهاى و ابعاد جههار گانه آن در ميان دانشآموزان نقش دارد. دســته ينجمر تحقيقاتى هستند كه به بررسى معيارهاى ارزيابى آموزش سواد رسانهاى و گجالشها يِيش روى آن مىيردازند.

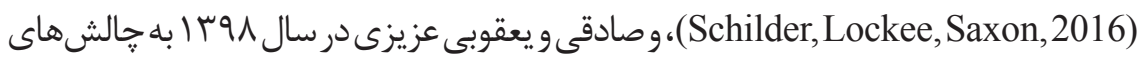
ارزيابى سواد رسانهاى يرداختهاند. دسته ششه، يزوهشهايى كه در صدد طراحى مدلهاى سواد رسانهاى براى نهادهاى اجرايى مسئول(مانند وزارت آموزش و يرورش، سازمان صدا و ســيما، وزارت آموزش عالى و حوزه علميه، خانوادهها و...) و بررسى وجوه اشتراك و افتراق سواد رســانهاى در كشورهاى مختلف مىيردازد. يزوهش هاى معتضدى (سوس (1)، فخارى

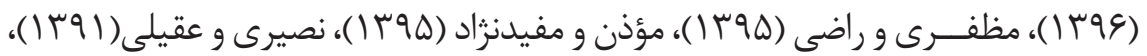
EUROPEAN COMMISSION, 20-22 (April, 2016), Sebastien Valvocrine, (1997) در اين زمينه اســت. نتايج مطالعه تطبيقى سيفى، عليقارداشى، غفارى و يويا (1 ب ا )، نشان داد نظام آموزشى كانادا و زاين، حكايت از روش معقول و سيستماتيك مى كند اما درايران هنوز اجراى الكوى مطلوب جاى بازنخرى دارد. دسته هفتمه، تحقيقاتى هستند كه شامل سياستخذارىهاى مرتبط با سواد رسانهاى مىباشد. علوى يور، عسخرى، خسروى و

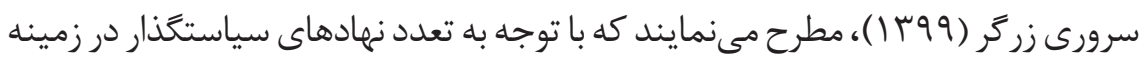


سواد رسانهاى درايران،اين امر با جالشهاى مختلفى مواجه است لذا آنها به بررسى جالشها

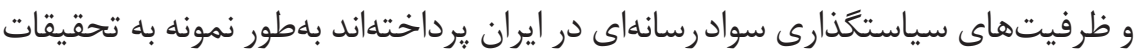

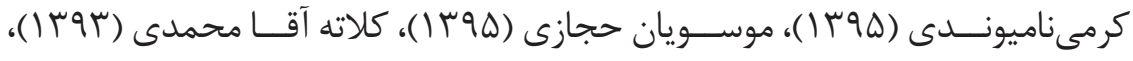

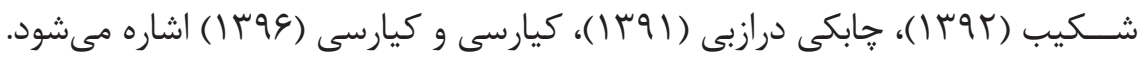
با توجه به دسـتهبندى ارائه شــده، يزوهش حاضر در دسته ششم؛ يعنى مدلهاى

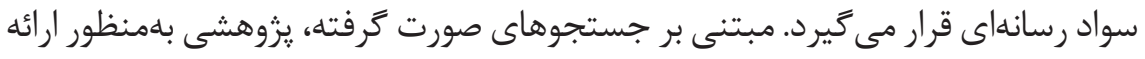

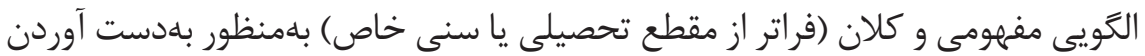

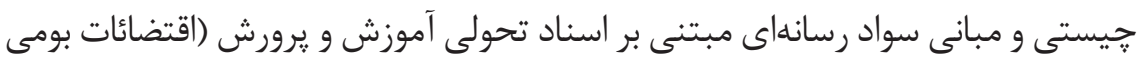

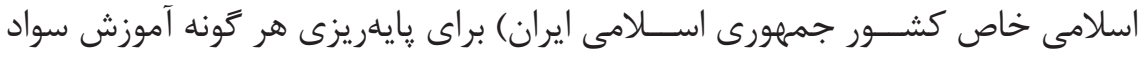
رسانهاى در كشور صورت نكَرفته است. يزوهشهاى انجام شده در دسته جهارم كه بيانكر

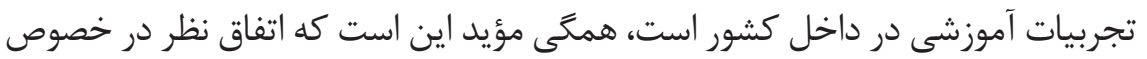

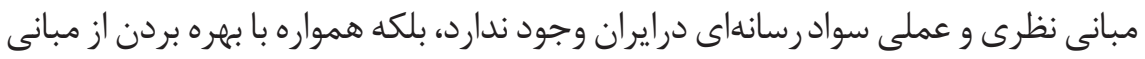

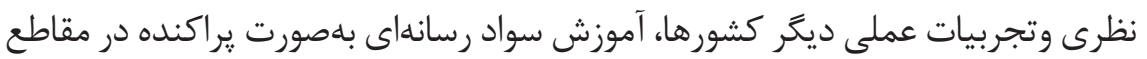

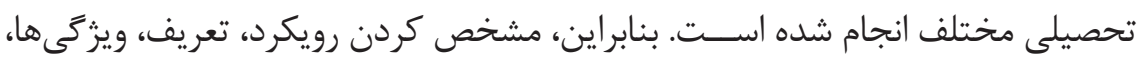

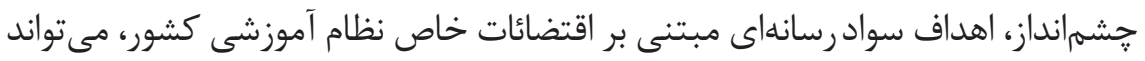

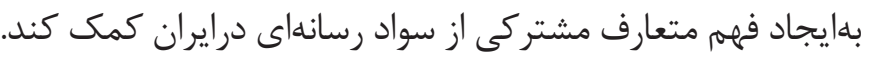

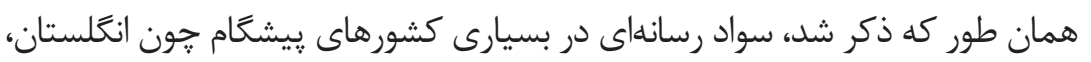

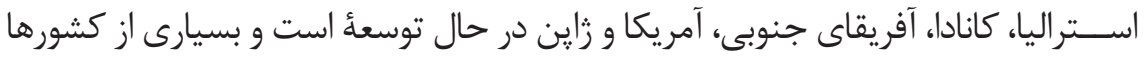

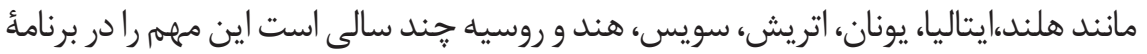

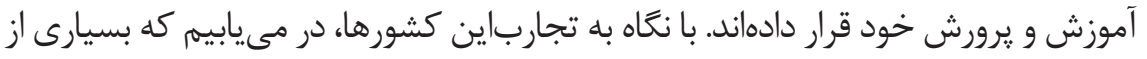

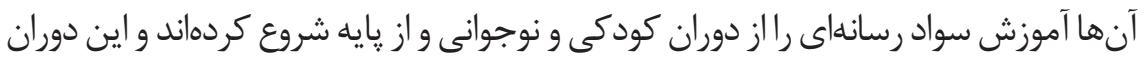

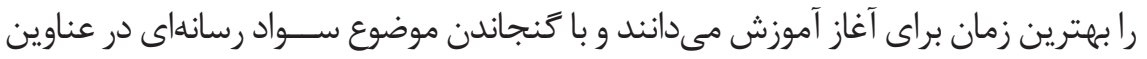

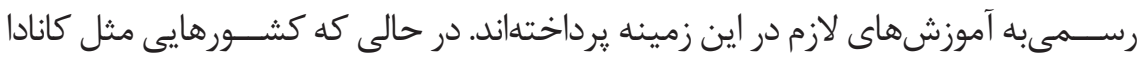

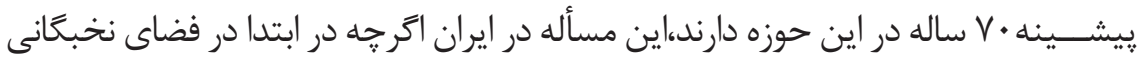

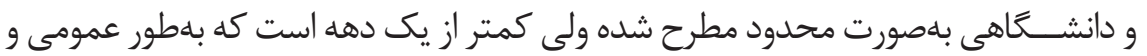
فراگير بدان يرداخته شده است و همجنان به ادبيات علمى و عملى متفاهم نرسيده و به شدت

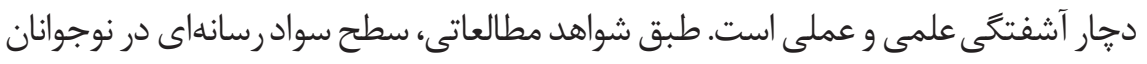




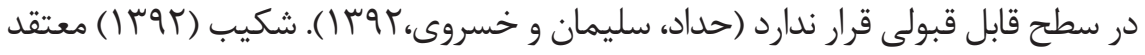
است اگر جه در اين راستا، كتاب تفكر و سواد رسانهاى از سال هوسا در يايه دهم تدريس شده است، اما خلاء طراحى الخوى سواد رسانهاى، براى مقاطع مختلف تحصيلى يا برجا است. با توجه به مطالب مطروحه، يزوهشــر در صدد اســت با بررسى تطبيقى مدلهاى آموزشى سواد رسانهاى در سه كشور كانادا، زاين و استراليا' و ضمن بهرهزيرى از تجارب

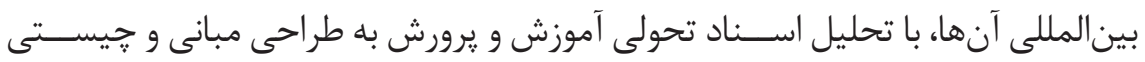

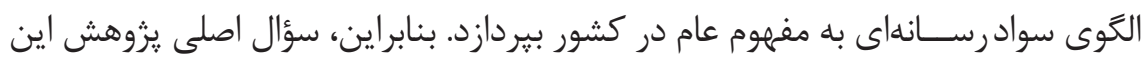
است الخوى مفهومى سواد رسانهاى بر اساس اسناد تحولى در نظام تعليهم و تربيت جمهورى اسلامى ايران جُگونه تبيين مىشود؟ و سؤالات فرعى ديخر كه ياسخ داده مىشود: () تفاوتهاو شــباهتهاى الگوى سواد رسانهاى در كشورهاى پيشرو (كانادا، زاين و

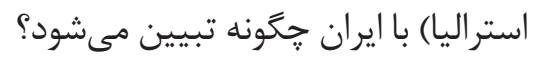

ץ) مبانى فلسفى سواد رسانهاى بر اساس اسناد تحولى در نظام تعليم و تربيت رسمى مئى

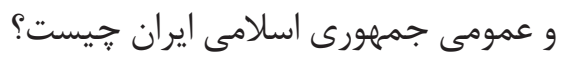

") رويكرد اصلى سواد رسانهاى بر اساس اسناد تحولى در نظام تعليمى و تربيت رسمى إنى

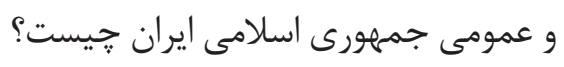

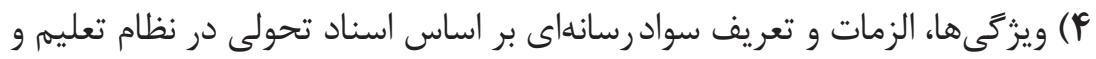
تربيت رسمى و عمومى جممهورى اسلامى ايران جيست؟ ه) جشمانداز و اهداف سواد رسانهاى بر اساس اسناد تحولى در نظام تعليم و تربيت

$$
\text { رسمى و عمومى جمهورى اسلامى ايران :جيست؟ }
$$

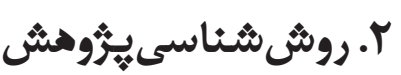

اين يثرهش از نظر هدف كاربردى از نوع توسعهاى است و شيوه اجراء، كيفى از نوع تطبيقى و تحليلى است. بهمنظور مطالعه تطبيقى تجربههاى كشورهاى ييشرو در زمينه

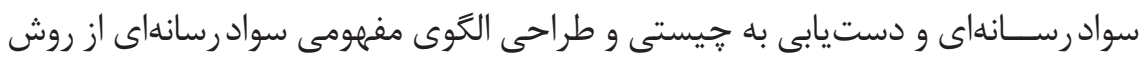
كتابخانهاى و اسنادى در روشهاى كيفى با رويكرد سند يزوهى مورد استفاده قرار گرفت.

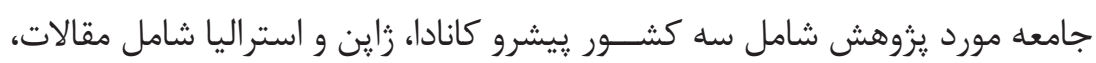


يروزهها و يزوهشهاى (قبلى)، شيوههاى آموزش، طرح درسها، اسناد و اطلاعات مربوط

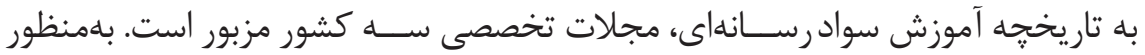

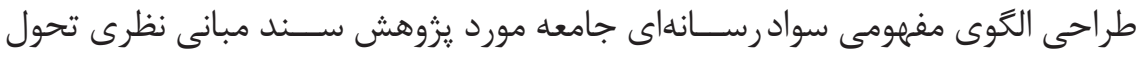
بنيادين (با محوريت ســند فلســفه تعليمه و تربيت در جمهورى اســلامى ايران، و نكاه تكميلى اسناد فلسفه تعليم و تربيت رسمى عمومى در جمهورى اسلامى ايران و رهنامه

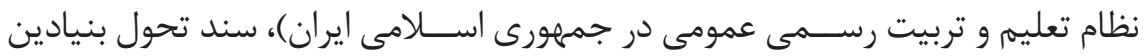

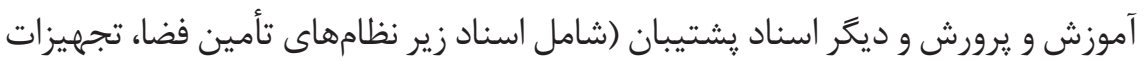
و فناورى، برنامة درسـى ملى، منابع مالـىى، يزوهش، راهبرى و مديريت و تربيت معلم)

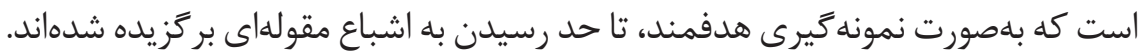

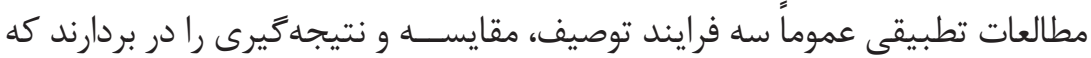
بدين جهت از روش كتابخانهاى و اسنادى استفاده شد و بهمنظور مقايسه نتايج بلهدست آمده

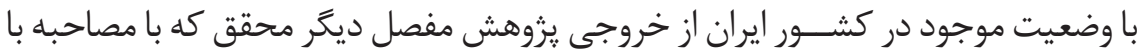
خبر كان صورت گرفته، استفاده شد و به مقايسه تطبيقى يرداخته شد. بلمنظور تحليل اسناد

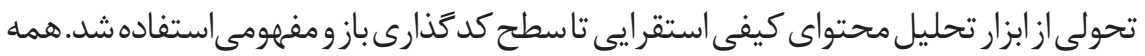
رويكردهاى تحليل محتواى كيفىازيكفرايندمشابه يِيروى لمى كنند (كهشامل Vمرحلهاست.): ( ) تنظيم كردن يرسشهاى تحقيقى كه بايد ياسخ داده شوند؛ ؟) برگزيدن نمونهى مورد

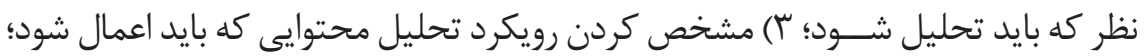

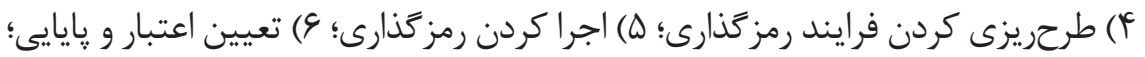

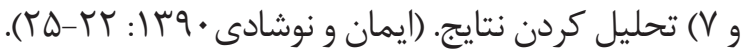

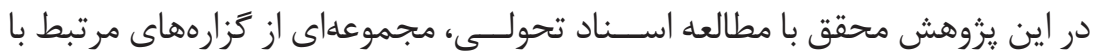
يزوهش را بركز يده و با رويكردى اســتقرايى، مؤلفههاى الكوى مفهومى سواد رســانهاى

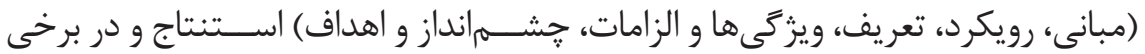

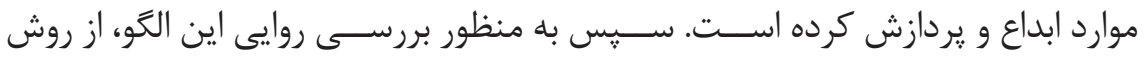
مثلثسازى' استفاده شد و علاوه براينكه كدگذارى ها با اشر اف يروهشكر بر حيطه مسئله مجدد مورد بررسى قرار گرفت، براساس نقد و بررسى صاحبنظر ان حوزههاى ارتباطات، مديريت آموزشى و تعليم و تربيت مورد جرح و تعديل نهايى قرار كرفت بردي. 


\section{فصلنامه (علمى-يثزوهشى)}

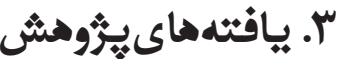

براساس يافتهها، در الخوى طراحى شده، مؤلفههاى مبانى فلسفى، ويزّى ها و الزامات، تعريف، رويكرد، جُشـــمانداز و اهداف سواد رســانه بهدست آمد و اولويتها و روابط ميان مؤلفهها در الكو مشخص شد. در ادامه به مباحث يرداخته مىشود.

\section{ץ-1. مطالعه تطبيقى تجارب كشور هاى ييشرو در سوادرسانهاى}

يافتهای مطالعه تطبيقى مدل هاى آموزشى سواد رسانهاى سه كشور ييشرو

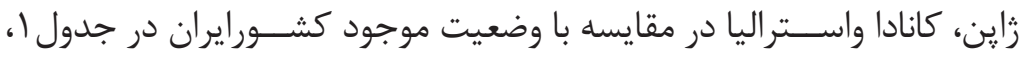
ارائه شده است. استنادات مطرح شده در خصوص وضعيت موجود كشور ايران در رابطه با سواد رســانهاى بر اساس خروجى بخش ديخرى از يزوهش است كه

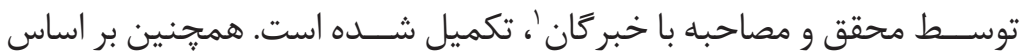
مطالعات نظرى و ييشـــينه يزووهشــى در ادامه در قالــب جدولى جمعبندى و

$$
\text { استنباط مقولات نظرى اوليه ارائه مىشود. }
$$

جدول ا. مقايسه مدلهاى آموزش سواد رسانهاى در جهار كشور يِيشرو

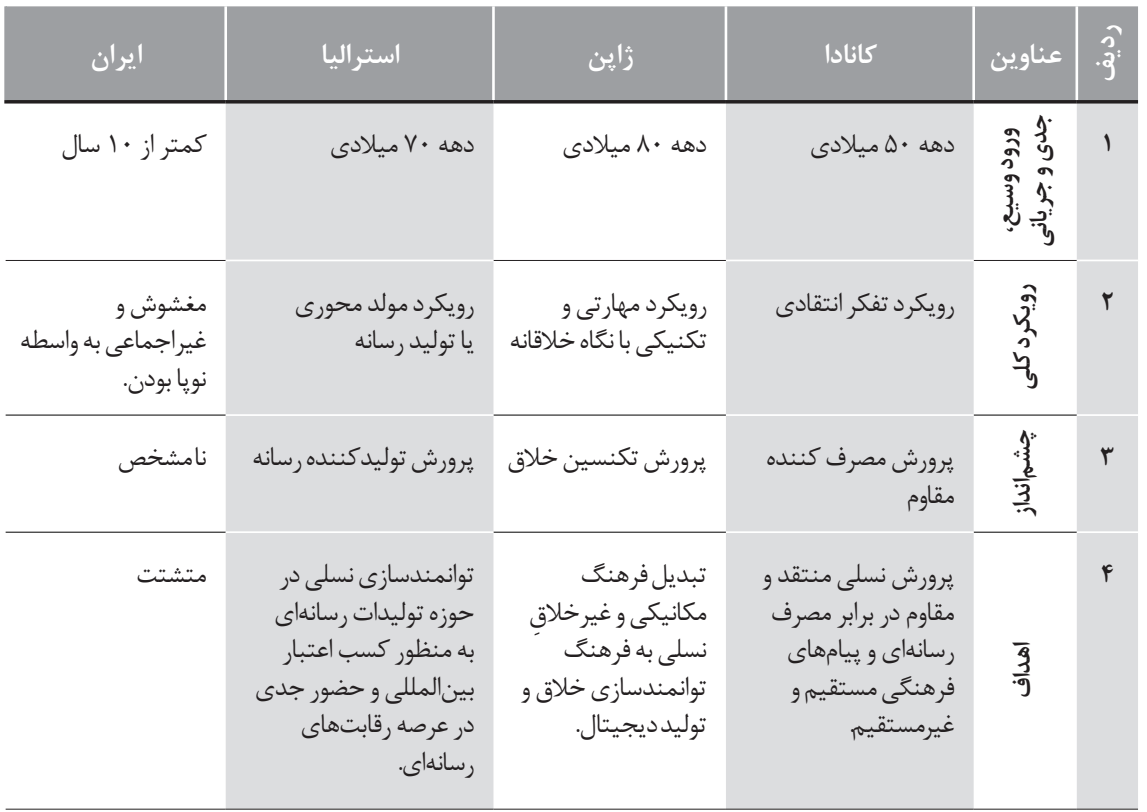

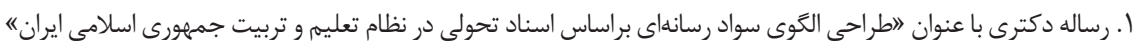

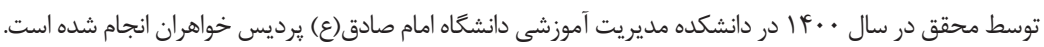




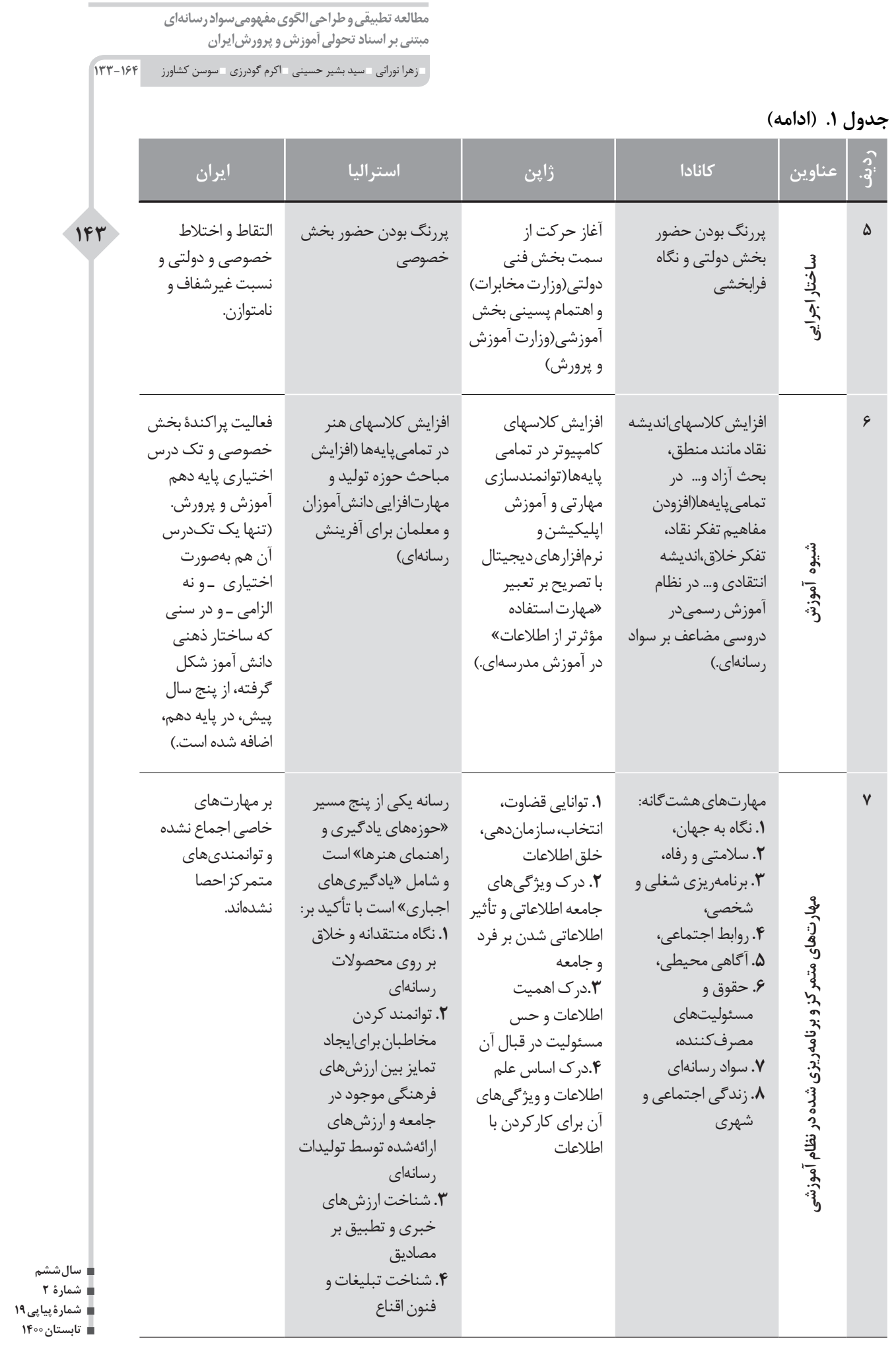




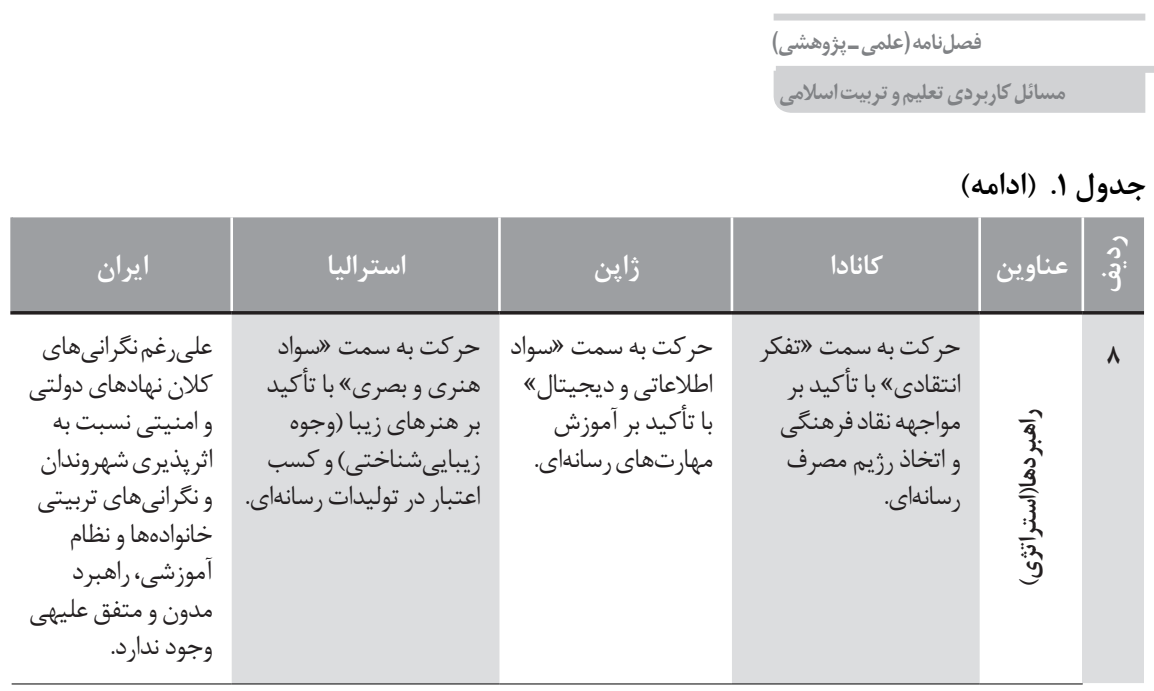

جدول r. مؤلفههاى الكوى اوليه مفهومى سواد رسانهاى

\begin{tabular}{|c|c|c|}
\hline توضيحات & مؤلفه هاى الكَوى روان & $\hat{\jmath}^{3}$ \\
\hline 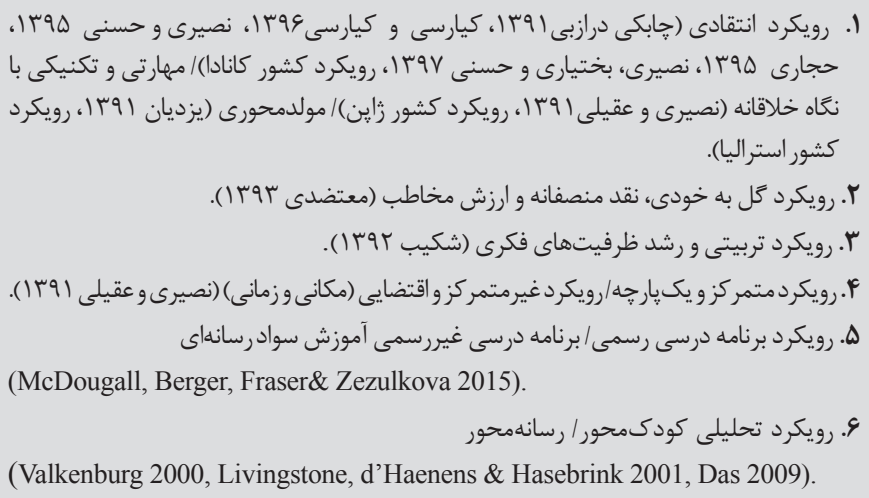 & رويكرد & 1 \\
\hline 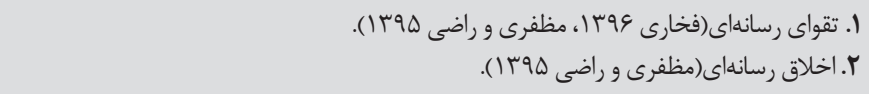 & مبانى & $r$ \\
\hline 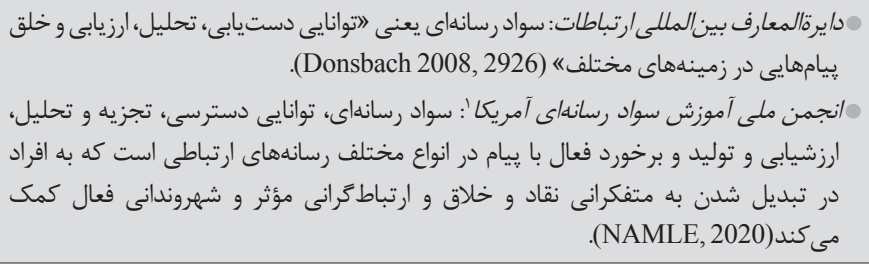 & مؤلفه تعاى سوراد & $r$ \\
\hline
\end{tabular}




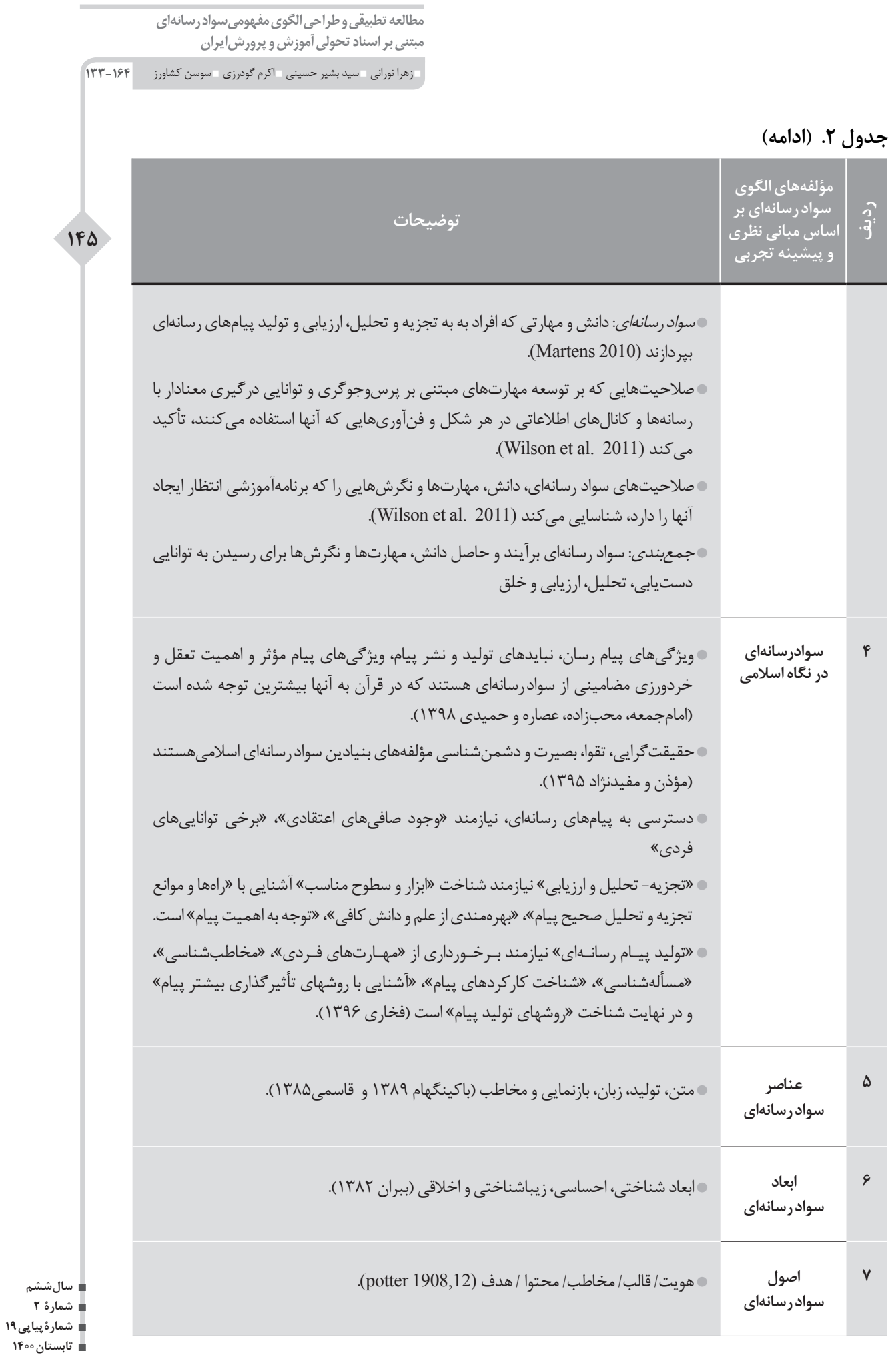




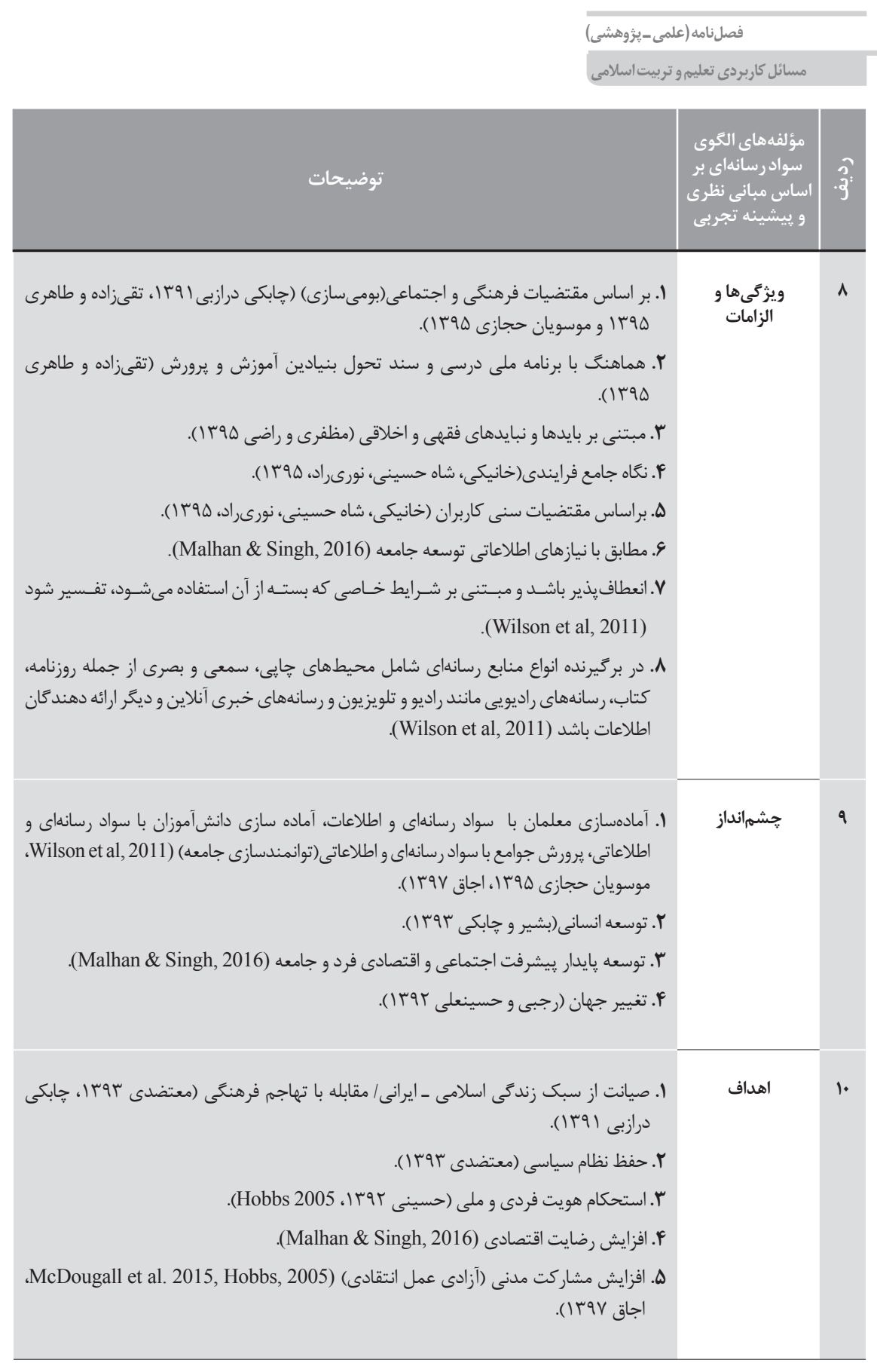




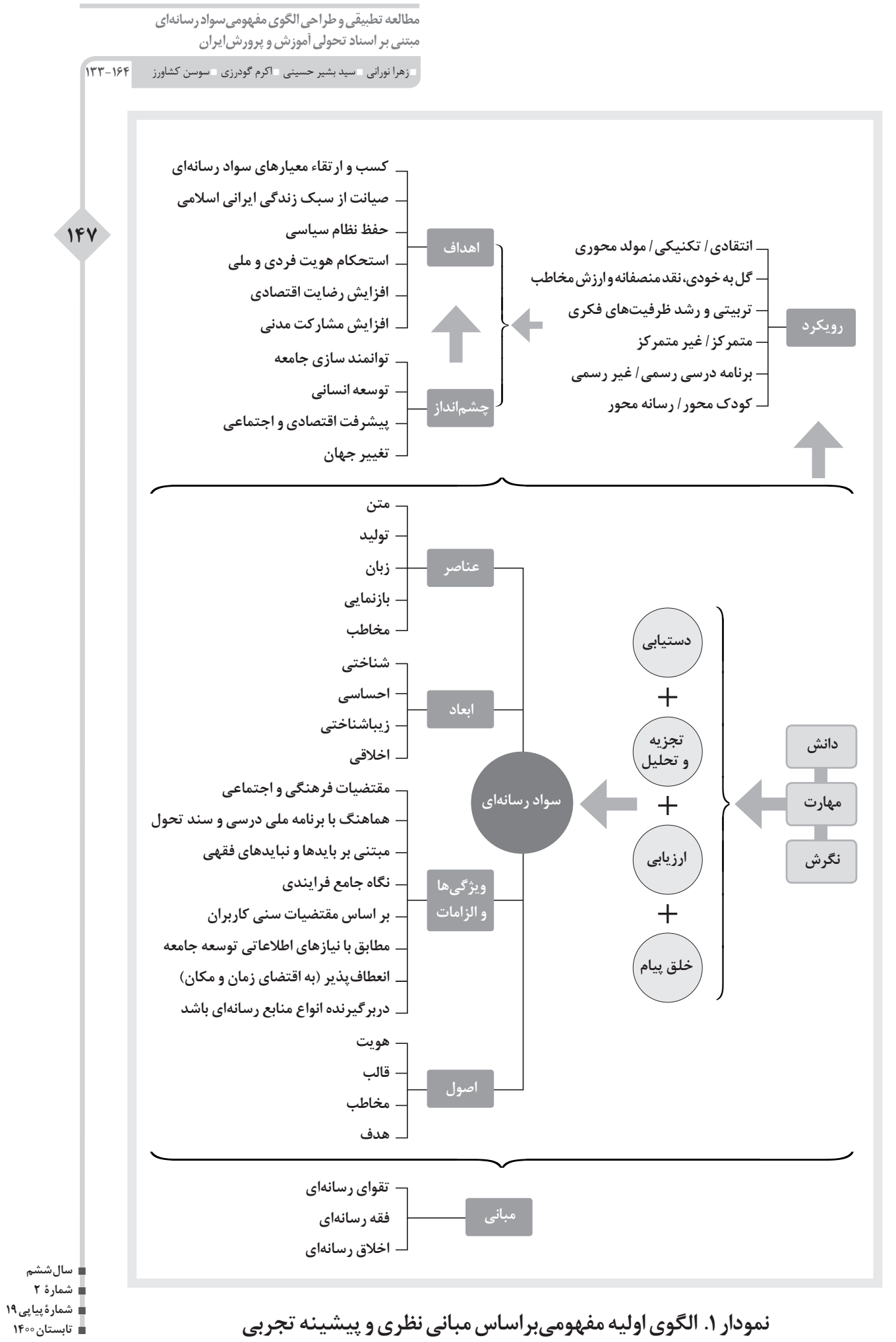




\section{r-r. - مبانى فلسفى سواد رسانه}

مبانى فلســفى شامل هستى شناسى، انسان شــــاختى، معرفتشناختى و

ارزششـــاختى است كه موارد مرتبط با رســـانه از سند اول مبانى نظرى سند

تحول بنيادين آموزش و يرورش (ســـد فلســفه تعليم و تربيت در جمهورى اســلامىايران) اخذ شـــده ســــ محقق تلاش نموده با احصاء كدهاى باز و

مقولهبندى، مرهمترين مبانى در مدل مشخص شود (طبقجدول ؟).

\section{جدول r. مقولات استنتاج شده از مبانى فلسفى سند مبانى نظرى سند تحول بنيادين}

\begin{tabular}{|c|c|c|c|c|c|}
\hline مقولات & زيرمقولات & كلها & متون (اسناد) & 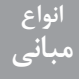 & . \\
\hline \multirow{8}{*}{$\begin{array}{l}3 \\
3 \\
3 \\
3 \\
3 \\
3 \\
3\end{array}$} & واقع گرايى & ماهيت دو مانه & جبه جبان هستى واقعيت دارد؛ ولى هستى منحصر نيست. (بلد نباشد) & \multirow{8}{*}{$\begin{array}{c}3 \\
3 \\
3 \\
3 \\
3 \\
3\end{array}$} & 1 \\
\hline & ربوبيت & خداوند مبدأ و منشأ جهان & 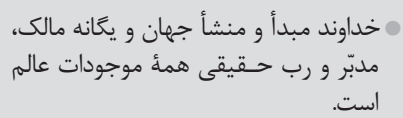 & & \\
\hline & نيازمندى & نياز محض موجودات & 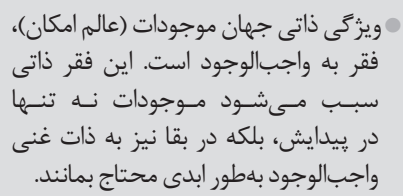 & & \\
\hline & تشكيك در مراتب & $\begin{array}{c}\text { كثرت در عين وحدت } \\
\text { (و بالعكس) }\end{array}$ & 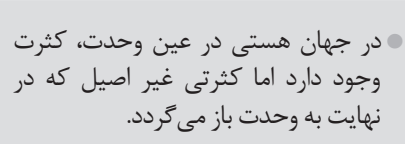 & & \\
\hline & \multirow[t]{3}{*}{ هدفمندى } & \multirow[t]{3}{*}{ غايتمندى جهان هستى } & غا آفرينش جهايت همه موجودات هستى، غايتمند و خداوند & & \\
\hline & & & اراده و سنن آفرينش از نظام احسن برخوردار و هـان & & \\
\hline & & & جهان هستى حلت و معلول و سبت است و مسبّب بر & & \\
\hline & 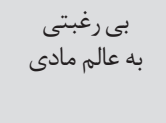 & فنايذيرى جهان طبيعت & 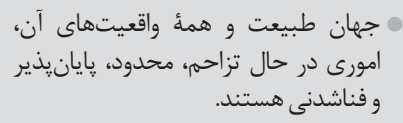 & & \\
\hline
\end{tabular}




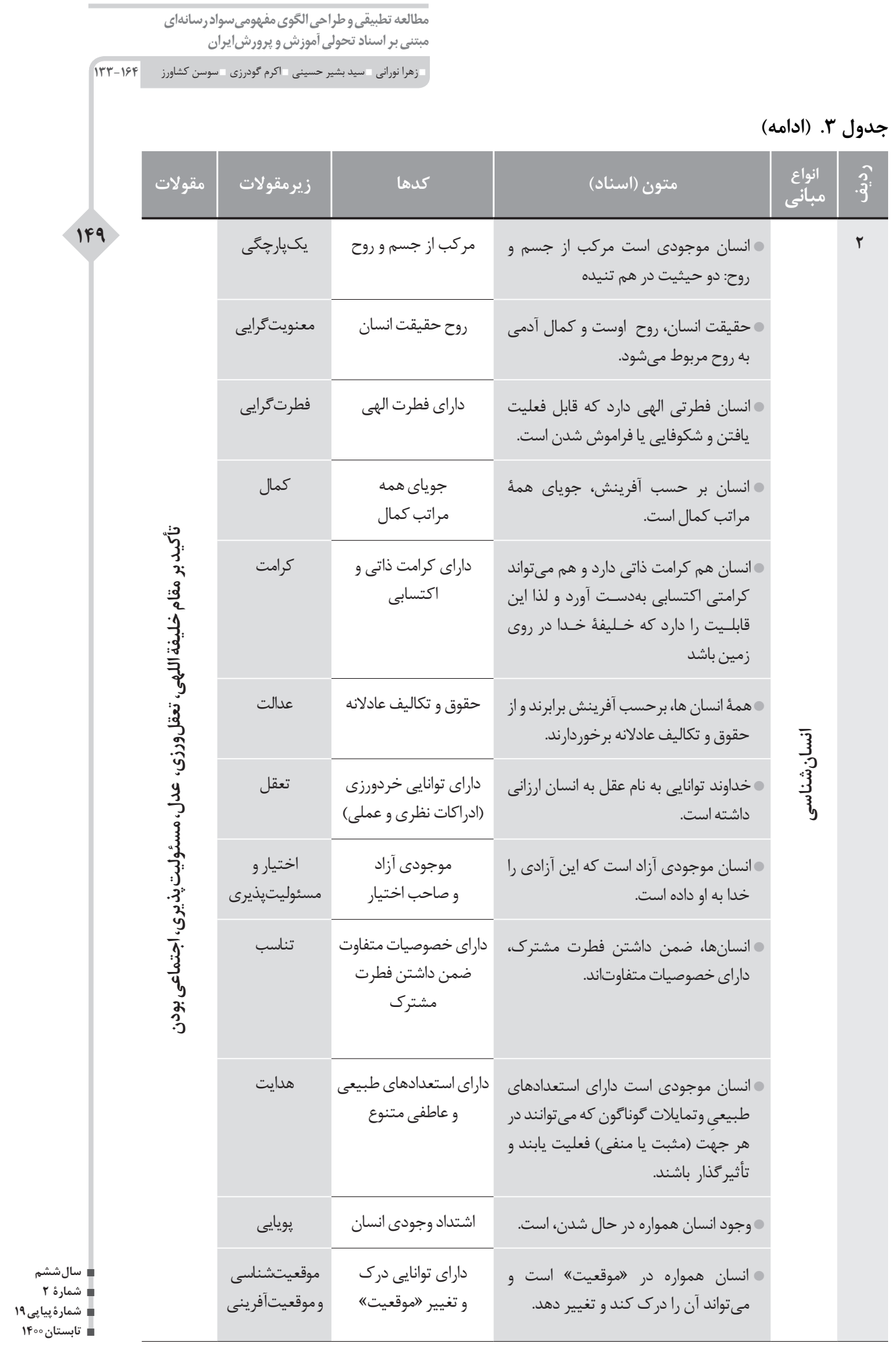


فصلنامه (علمى_يثوهشى)

مسائل كاربردى تعليمو تربيت اسلامى

جدول r. (ادامه)

\begin{tabular}{|c|c|c|c|c|c|}
\hline مقولات & زيرمقولات & كدها & متون (اسناد) & مبانى انواع & $\hat{\grave{j}}$ \\
\hline & انسان أثير و تأثر & انسان موجودى اجتماعى & 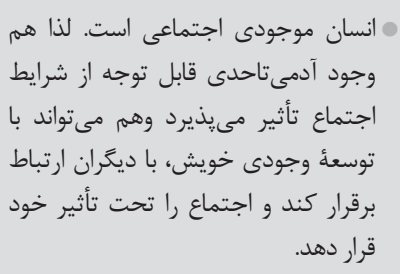 & & \\
\hline 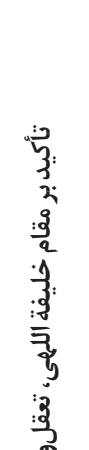 & هويتيابى & 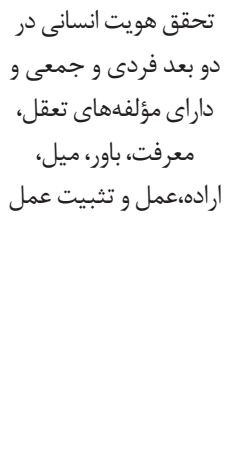 & 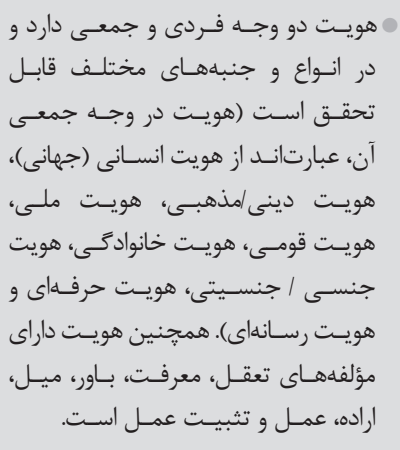 & & \\
\hline 童 & تكليفكرايى & موجودى مكلف & 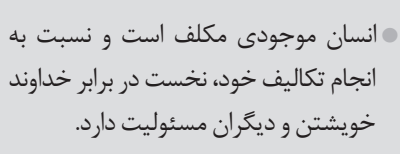 & 3 & \\
\hline $\begin{array}{l}3 \\
3 \\
3 \\
3 \\
5 \\
\vdots \\
3 \\
4 \\
3 \\
2 \\
3 \\
.3\end{array}$ & اسوهرايى & ديازمند تولاو تأسى به دماديق كامل انسان & 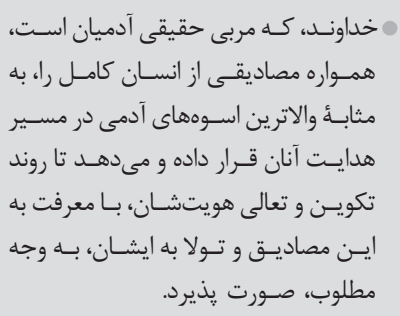 & & \\
\hline & آخرترايى & ت اخروى بريايه تكوين و جاوداته انسان در حيات & 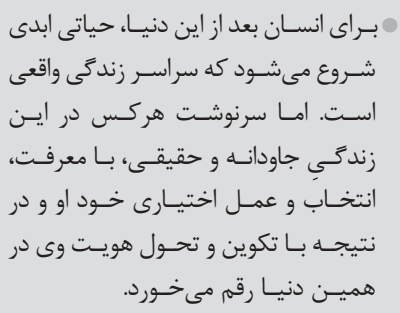 & & \\
\hline
\end{tabular}




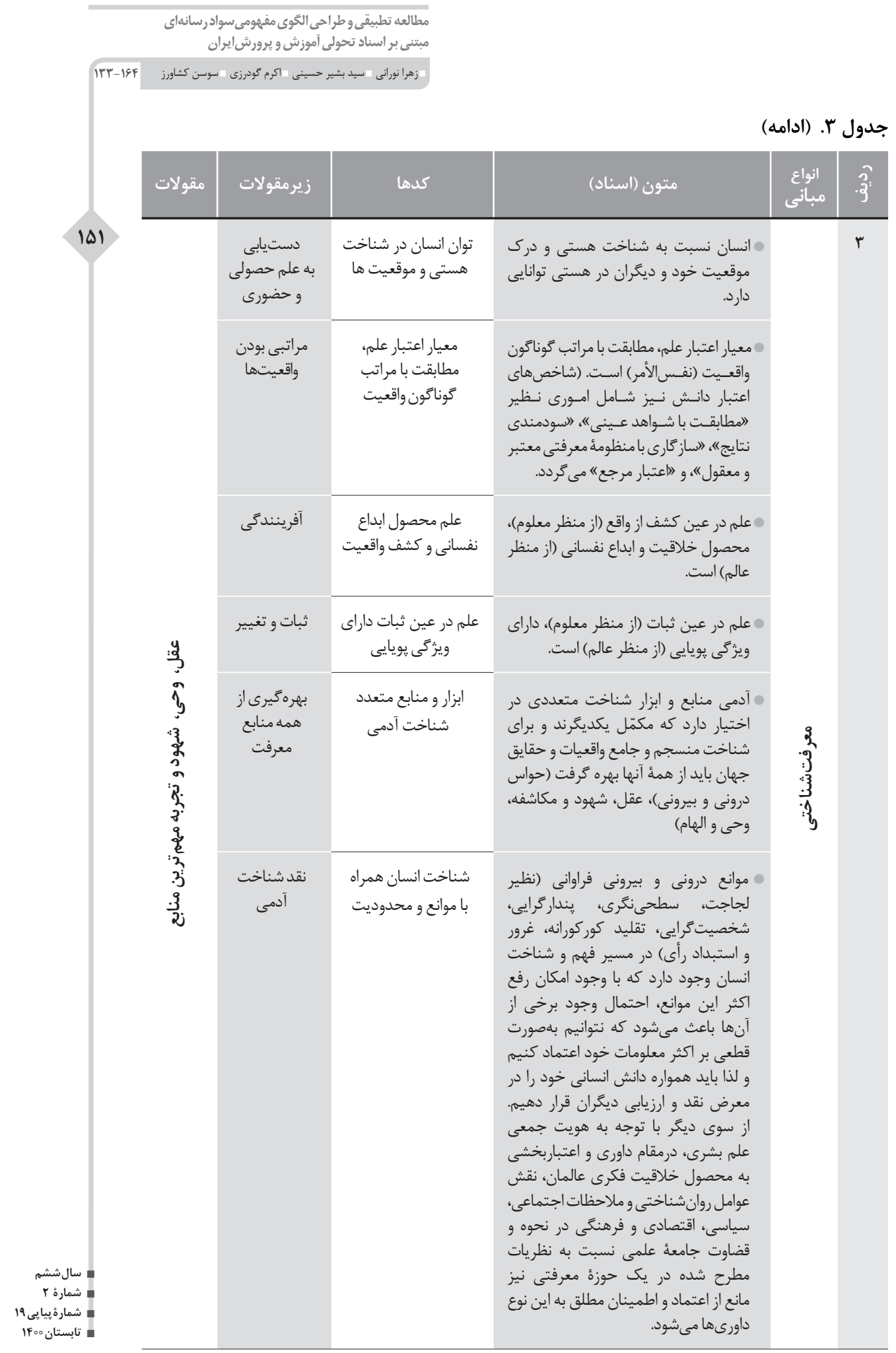




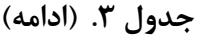

\begin{tabular}{|c|c|c|c|c|c|}
\hline مقولات & زيرمقولات & كلها & متون (اسناد) & 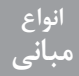 & 3 \\
\hline & عمل گرايى & تكيه اعتبار ارزشهاى & مربوطبار ارزشه عمل آدمى حقيقى بر و واقعيتهايج آن تكيه دارد. & \multirow{8}{*}{$\begin{array}{l}\overline{2} \\
.3 \\
3 \\
3 \\
: 3\end{array}$} & f \\
\hline & 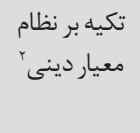 & و " اعقل و فطرت انسانى" دعتبار دينى هنبع ارزشها & 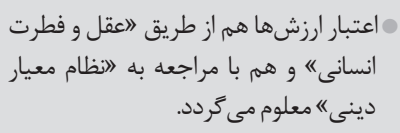 & & \\
\hline 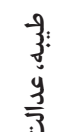 & تقرب & 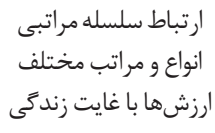 & 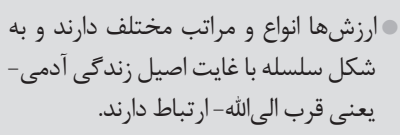 & & \\
\hline$\stackrel{3}{3}$ & توجله به حسن فئ فلى فلى & 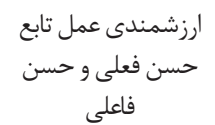 & فرارزشى و هم وابسته دانستن هر عُمل، همن تابع حُسن استى & & \\
\hline 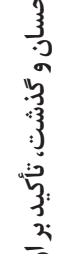 & حست ل & حيات طيبه هدف غايى & 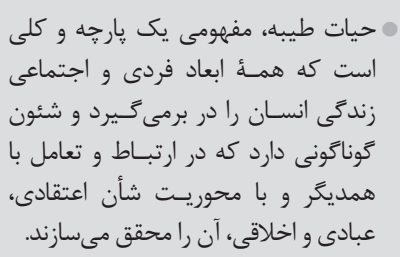 & & \\
\hline $\begin{array}{l}3 \\
3 \\
3 \\
3 \\
3 \\
3 \\
3 \\
3 \\
3 \\
3\end{array}$ & \multirow[t]{2}{*}{ جلمتيت و جلمال } & \multirow[t]{2}{*}{ حيات طيبه امرى ذومراتب } & 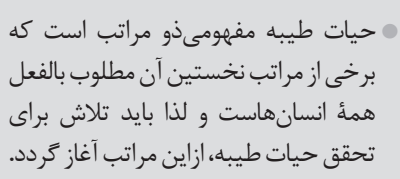 & & \\
\hline & & & 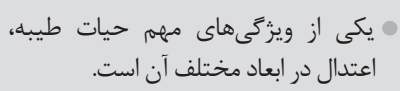 & & \\
\hline & ولايت يذيرى & 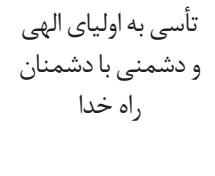 & 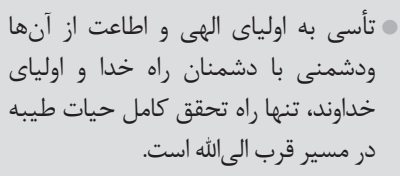 & & \\
\hline
\end{tabular}

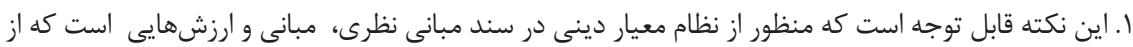

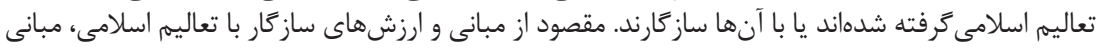

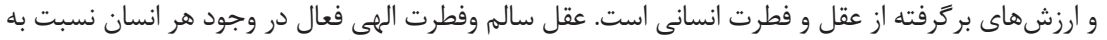

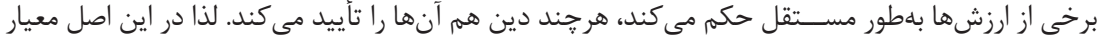

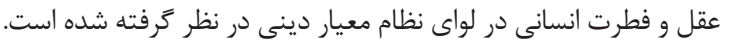




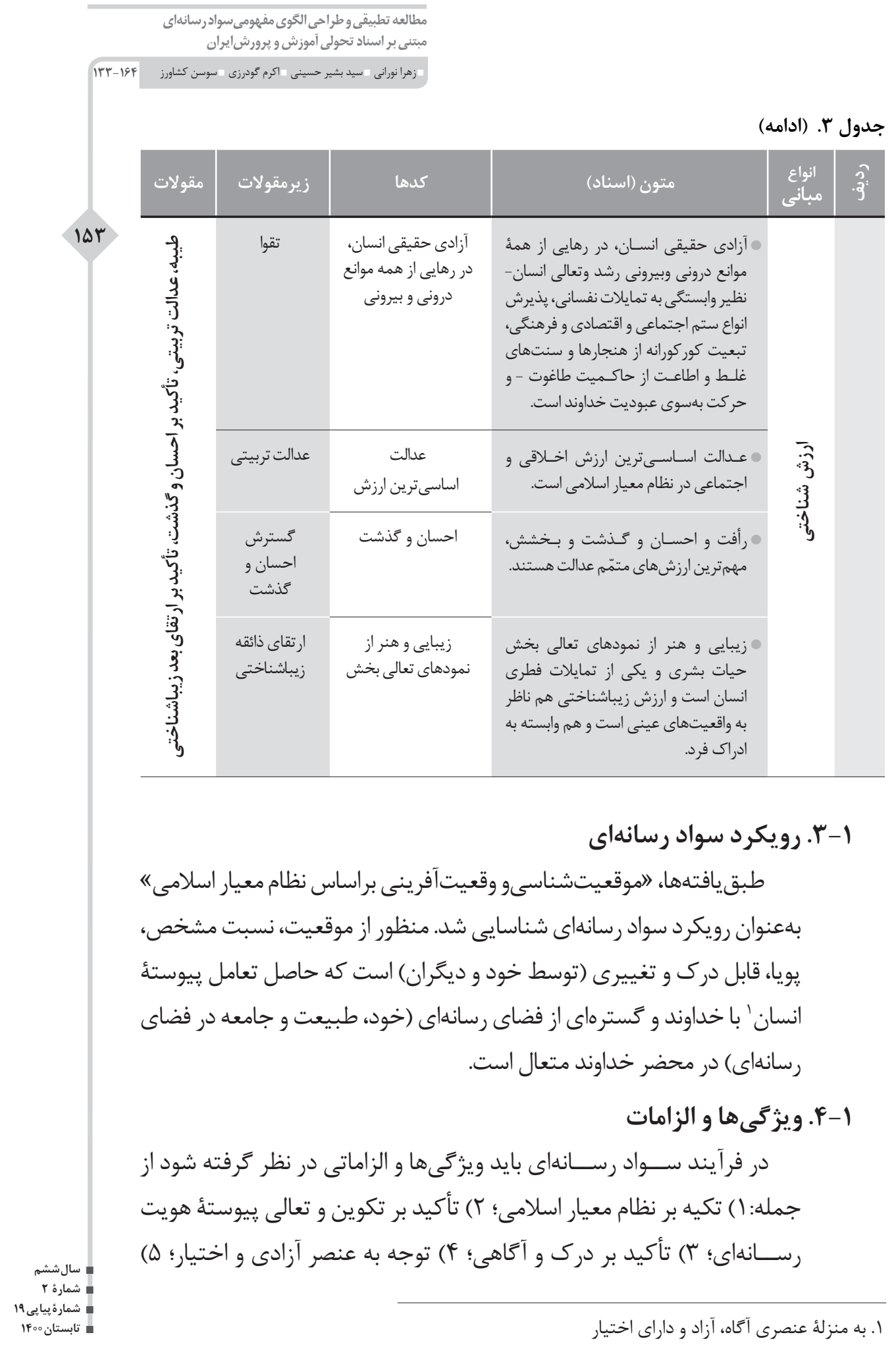




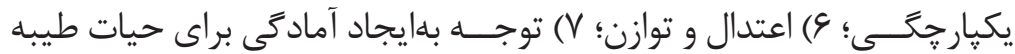

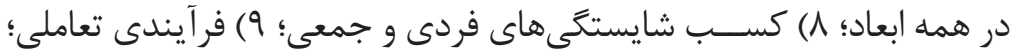

$$
\text { •) (1) زمينهسازى و ( () هدايت. }
$$

\section{|-ه. تعريف سواد رسانهاى}

سوادرسانهاى فرايندى تعاملى زمينهســاز كسب شايستخى هاى فردى و جمعى (تعقل، معرفت، باور، ميل، اراده، عمل فردى و جمعى و تثبيت عمل) براى رسيدن به توانايى كشف عناصر موقعيت رسانهاى و برقرارى نسبت بين آنها با خداوند متعال، درك درست موقعيت رسانهاى خويش و ديخران، عمل مداوم فردى و جمعى براى بهبود آن (خلق مداوم موقعيت رسانهاى) در انواع فضاهاى رسانهاى به منظور تكوين و تعالى ثيوسته هويت رسانهاى' متربيان، بلهورتى يكيار جه و مبتنى بر نظام معيار اســلامى (مجموعهاى منســــمه از مبانى و ارزشهاى بركرفته از منابع معتبر دين اســلام يا ســاز كار با آن)، در جهت هدايت ايشــان در مسير آماده شــدن جهت تحقق آكاهانه و اختيارى مراتب حيات طيبه (زندگى شايســــه براســاس نظام معيار اسلامى) در همءٔ ابعاد است.

كشــف عناصر موقعيت رسانهاى، شــامل مهارتهاى: () فهميدن تأثير فزاينده رسانه بر جامعه؛ ؟) فهميدن اين كه رسانهها جطور ساخته شدهاند؛ و ץ) فهميدن اين كه رسانهها جطور واقعيت را تغيير مى دهند، مىشود. درك درســت موقعيت رسانهاى شــامل: (1) مهارتهاى امكان استفاده كردن از تجهيزات، نرمافزار و برنامههاى كاربردى؛ ؟) آشــنايى با محيطهاى

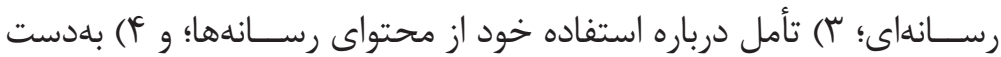

$$
\text { آوردن و يردازش اطلاعات است. }
$$

همجنين عمل مداوم فردى و جمعى براى بهبود موقعيت رســانهاى خود و ديكران شــامل مهارتهاى: () توليد محتوا؛ ؟) مشـــاركت در شــــكههاى

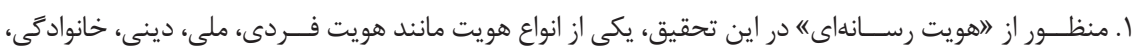

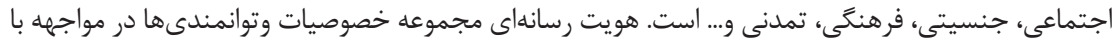

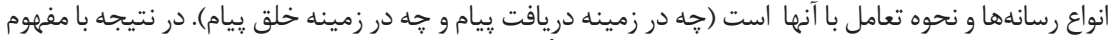

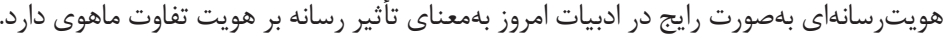


مطالعه تطبيقى وطراحى الكَى مفهومى سواد رسانهاى

مبتنى بر اسناد تحولى آموزش و يروريقي مفروايران

$1 r r-194$

اجتماعى؛ و ؟) دست يابى به هدف غايى تكوين و تعالى بيوسته هويت رسانهاى در جهت رسيدن به حيات طيبه است.

التكوين وتعالى ييوســتهُ هويت رســانهاى متربيان بهَونهاى كه بتوانند

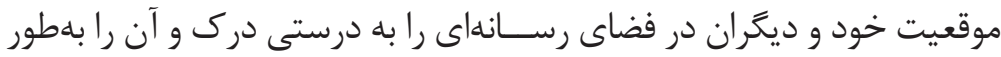
مستمر با عمل فردى وجمعى متناسب با نظام معيار اسلامىاصلاح نمايندها.

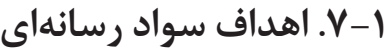

ه شناخت و بهرهگيرى از نتايج تجارب متراكم بشرى در حوزهُ سواد رسانهاى

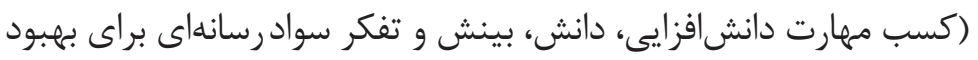
كيفيت زندگى، تفكر انتقادى در مواجهه با مســائل زندگى) بر اساس نظام معيار اسلامى؛ هبهر خيرى از يافتههاى سواد رسانهاى جهت كشف صورتهاى جديد واقعيت يــا خلق روشهاو ابزارهاى نوين براى وصول به اهداف در جهار خوب نظام معيار اسلامى؛

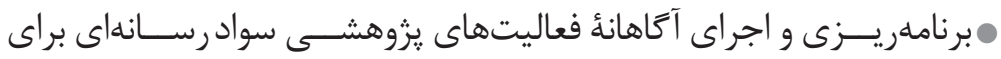
دست يابى به آيندة مطلوب بر مبناى معيار اسلامى؛

\section{1-1. الكوى مفهومىسواد رسانهاى}

در الكوى طراحىشــده روابط ميان مؤلفهها اينكونه تبيين شداء براساس مبانى فلســفى - واقعيتهستى، ماهيت انسان، معرفت و ارزشها، ويزّكى ها و

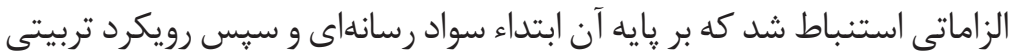

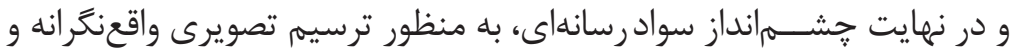
مطلوب از آينده سواد رسـانهاى مطرح شد. يافتهها طبق (نمودار ؟) نشان داده 


$$
\text { مبانى فلسفى سواد رسانهاى }
$$

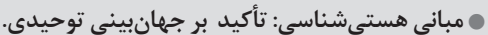

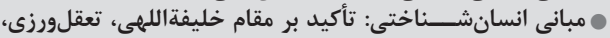

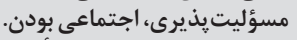

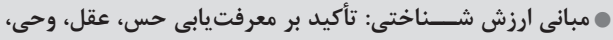

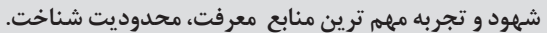

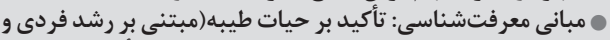

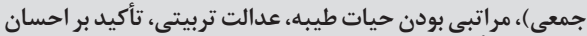
و حذشت، تأكيد بر ارتقاى بعد زيباشناختى

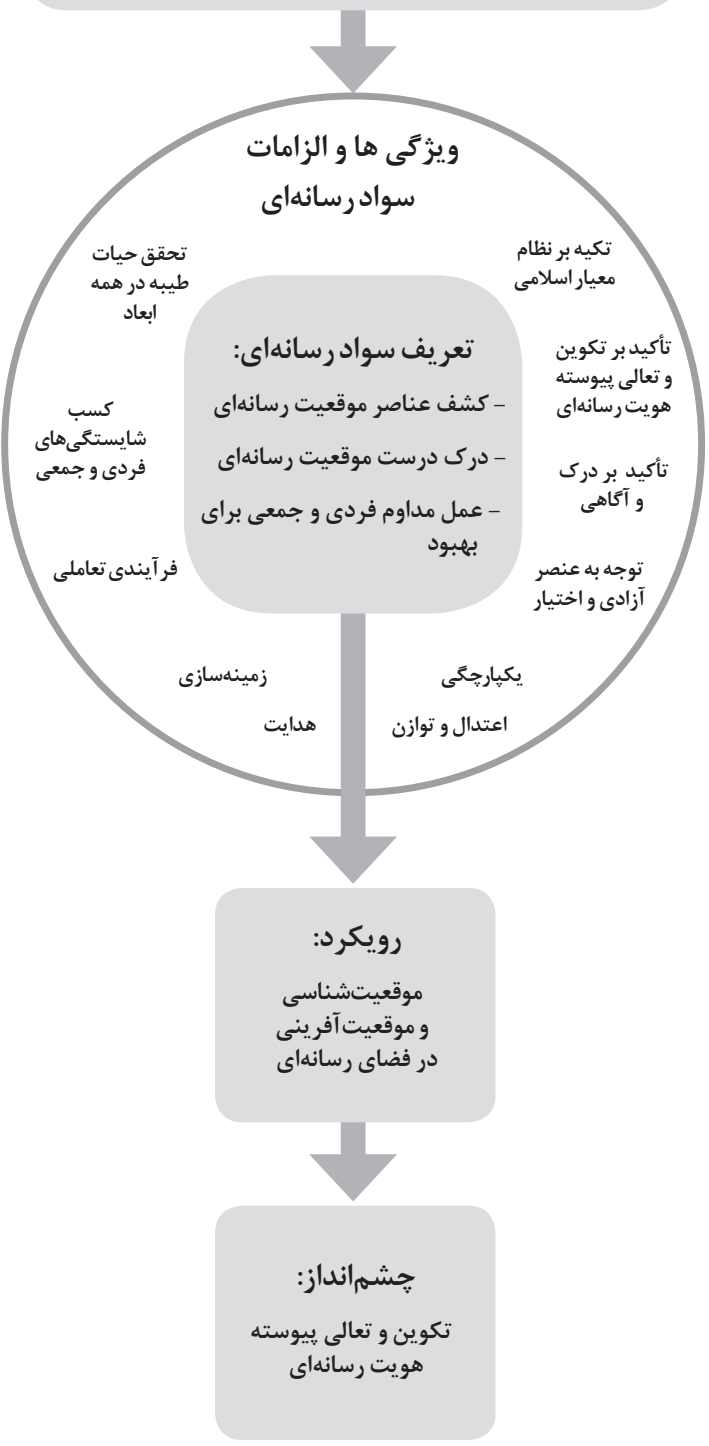


مطالعه تطبيقى وطراحى الخوى مفهومى سواد رسانهاى

مبتنى بر اسناد تحولى أموزش و يرورشايران مفيران

زهرانورانى سيد بشير حسينى اكرم كودرزى سوسن كثاورز

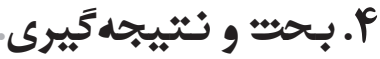

به منظور پاسخكويى به سؤال اصلى يُزوهش، الكَوى مفهومى سواد رسانهاى بر اساس اسناد

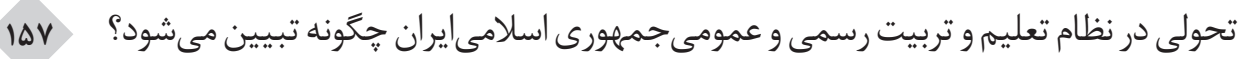

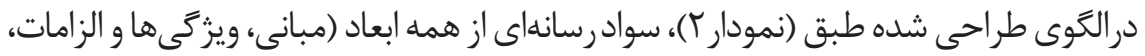

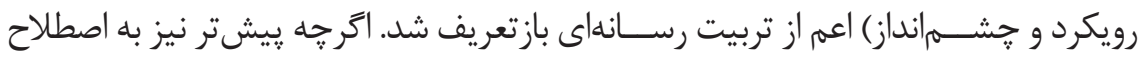

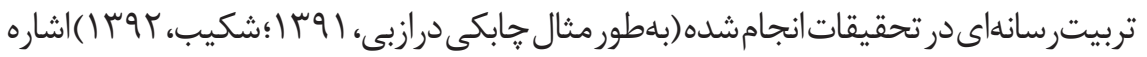
شده، اما دراين يزوهش بهصورت متقن اصطلاح سواد رسانهاى براساس اسناد تحولى باز تعريف

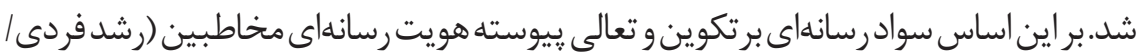
جمعى) براساس حيات طيبه با رويكرد موقعيتشناسى و موقعيتآفرينى در فضاى رساس رسانهاى

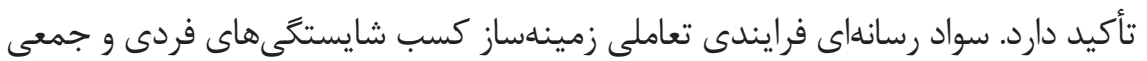

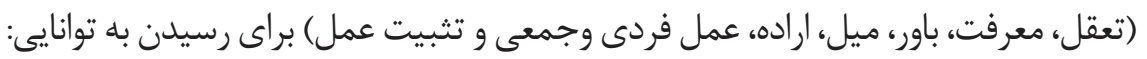

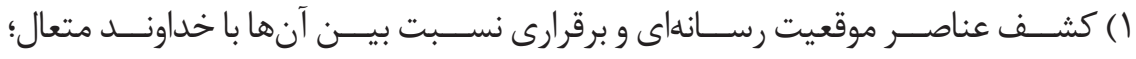

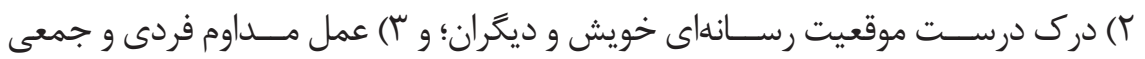

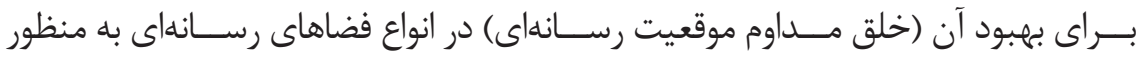

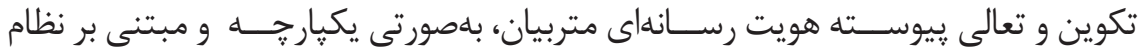

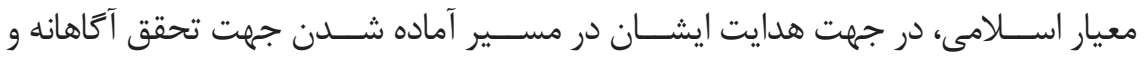

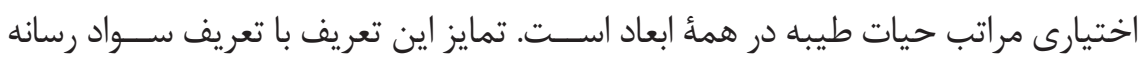

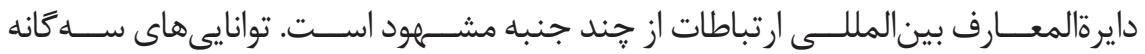

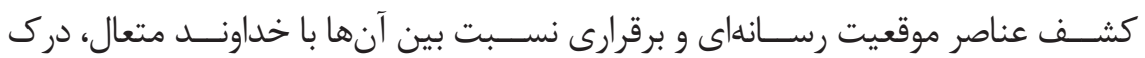

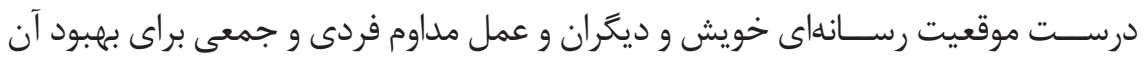

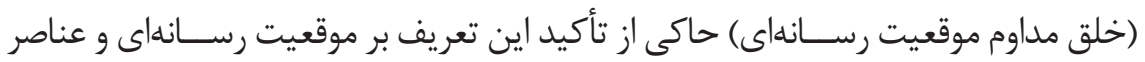

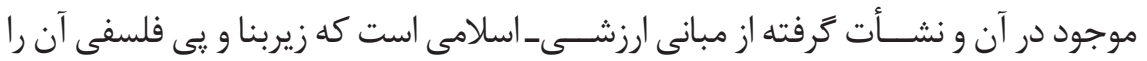

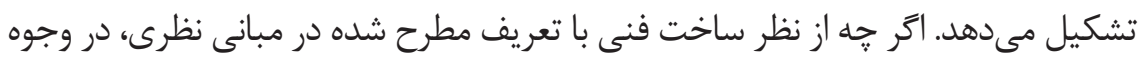

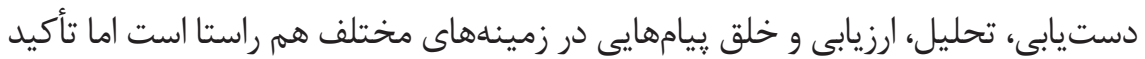

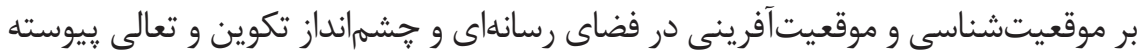

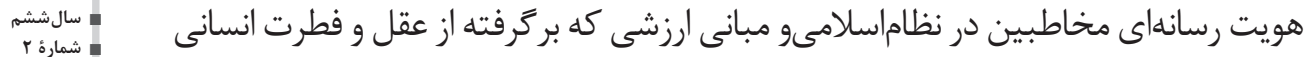

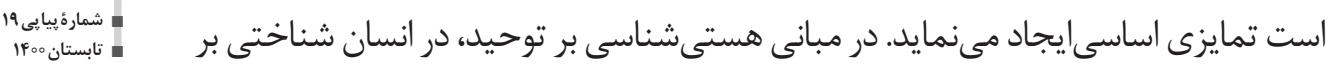


مقام خليفةاللهى، تعقلورزى، عدل، مسئوليتيذيرى، اجتماعى بودن، در معرفتشناختى بر معرفتيابى، حس،عقل، وحى، شهود و تجربه بهعنوان مهمترين منابع معرفت و محدوديت شـــناخت، و در مبانى ارزششناختى بر حياتطيبه (مبتنى بررشد فردى وجمعى)، مراتبى بودن حيات طيبه، تقواى رسانهاى، عدالت تربيتى، احسان و كذشت، ارتقاى بعد زيباشناختى

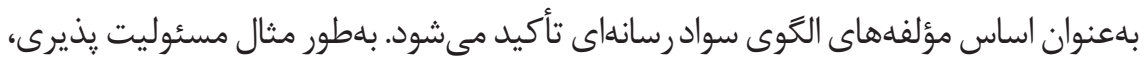

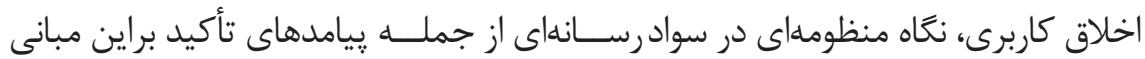
ارزشمند است.

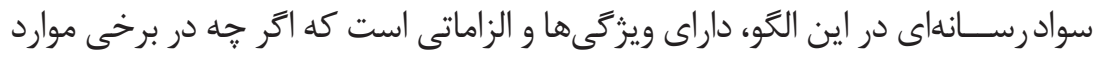
رويكردهاى موجود در اين زمينه همخوانى دارد اما در برخى از موارد تفاوت مفهومى دارد و يا مباحث تازهاى مطرح شده است. باطور مثال خانيكى، شاه حسينى، نورىراد (هوس |) از نغاه جامع فرايندى به سواد رسانهاى براساس مقتضيات سنى كاربران صحبت مى كنند و بر ويزگى الفر آيندى تعاملى" تأكيد دارد كه علاوه بر خاصيت فرآيندى بودن سواد رسانهاى بر تعاملى بودن تربيت بين مربى و متربى اشاره مى كند. تقىزاده و طاهرى (هوس ( ) از هماهنگى سواد رسانهاى با برنامه درسى ملى و سند تحول بنيادين آموزش و يرورش صحبت مىنمايند،

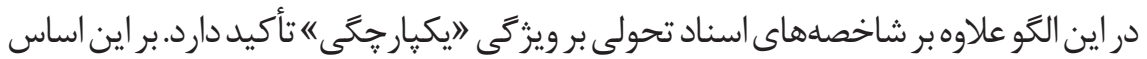
"اسواد رســانهاى" را بايد عملى جامع و يكيار جهه، تدريجى، هماهنگ، فراخير و هميشگى و

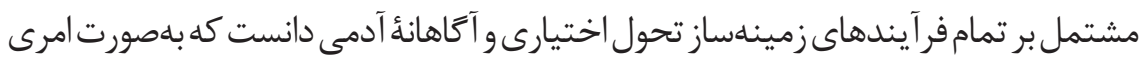
واحد، با تعالى ييوسته و يكيار جهُ تمام ابعاد فردى و اجتماعى وجود انسان، به منزلهُ يك كل،

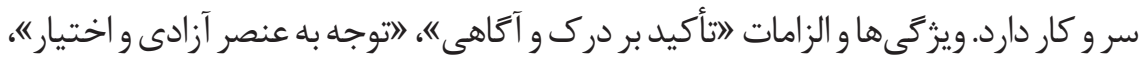

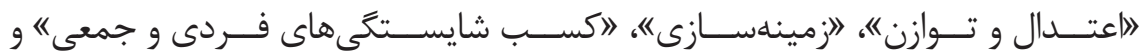
"هدايــت آر جه ممكن اســت در ديخر رويكردها موجود باشـــند، در اين الخو با رويكرد بومى ـ اســلامىمورد نظر قرار گرفتهاند و در كنار يكديگر رويكرد جامع و تازهاى بهوجود آوردهاند. ويزگى هايى مانند اتكيه بر نظام معيار اســلامى"، ل توجه بهايجاد آمادگى براى حيات طيبه در همه ابعاده، الأكيد بر تكوين و تعالى ييوسته هويت رسانهاى" نقطه تمايز اين الخو باديخر الخوهاى موجود است.

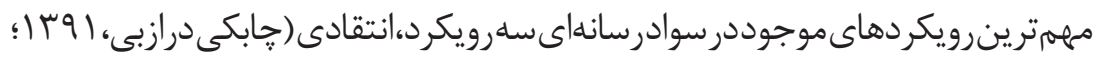

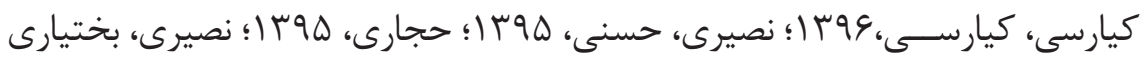


مطالعه تطبيقى وطراحى الخوى مفهومى سواد رسانهاى

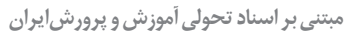

زهرانورانى سيد بشير حسينى اكرم كودرزى سوسن كثاورز

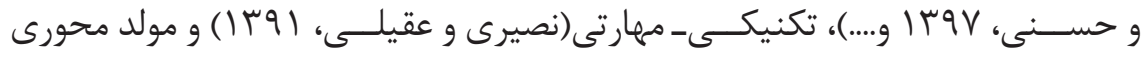
(Hobbs, 1998) رويكردها در قالب جدولى (شماره| ) مطرح شدند.

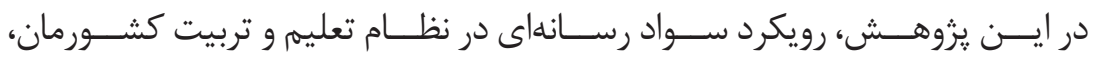
"اموقعيتشناسى و موقعيتآفرينى در فضاى رسانهاى بر اساس نظام معيار اسلامى " است.

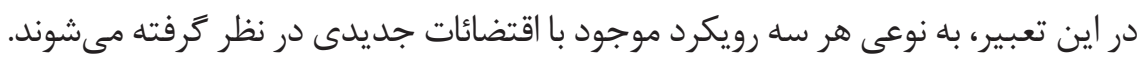

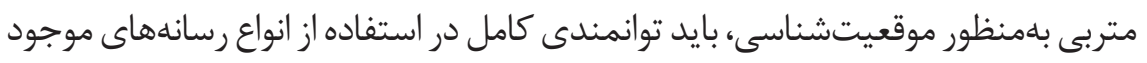

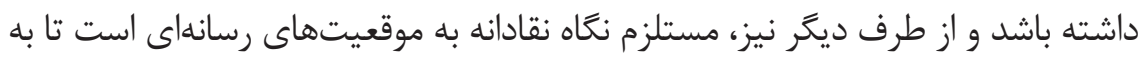

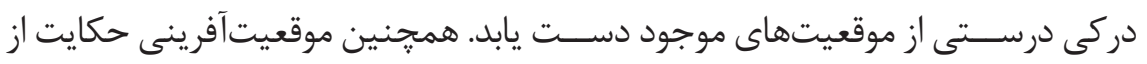

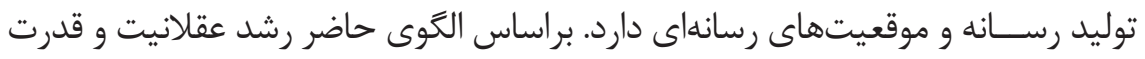

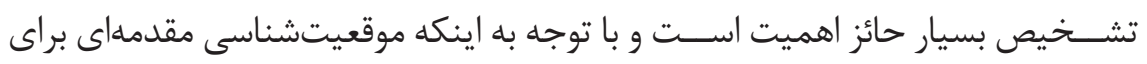

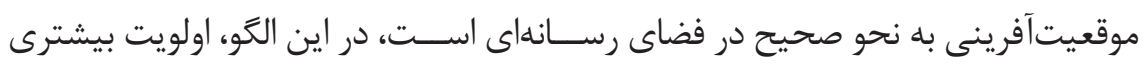

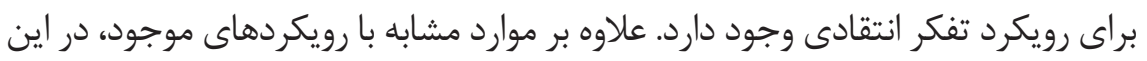

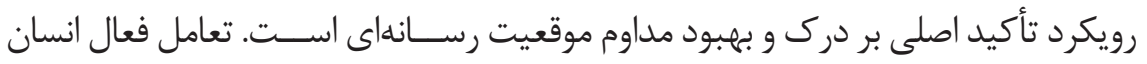

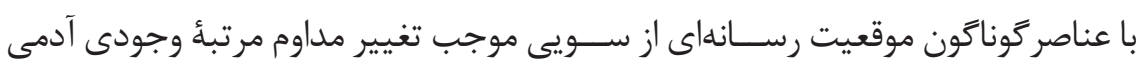

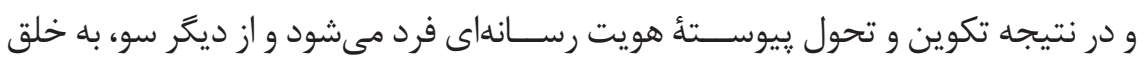

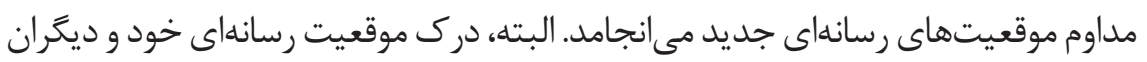

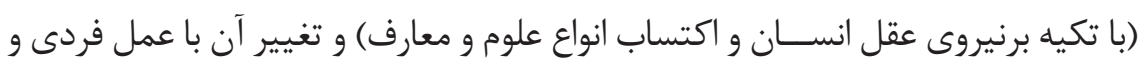

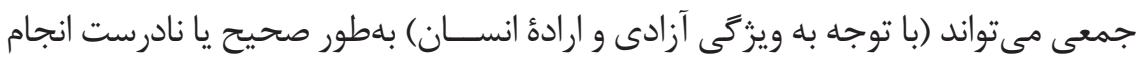

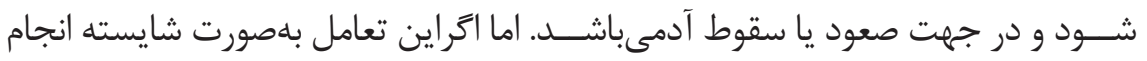

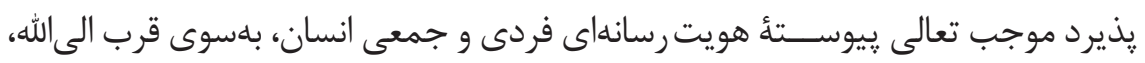

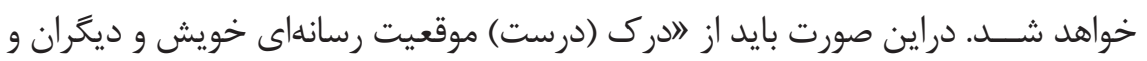

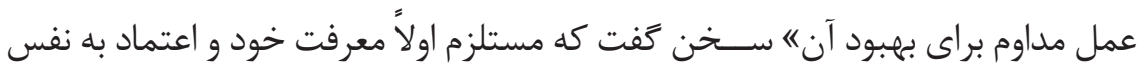

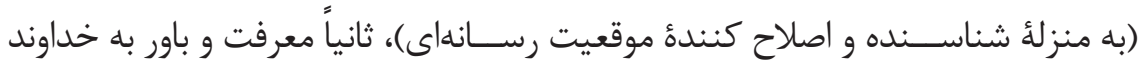

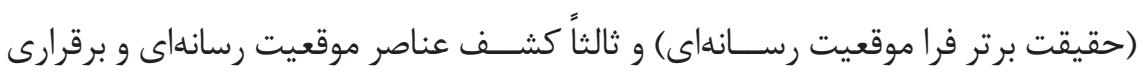

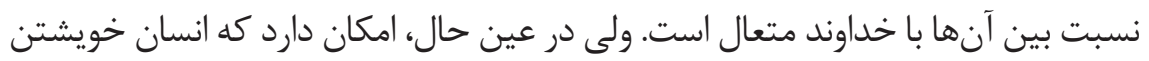

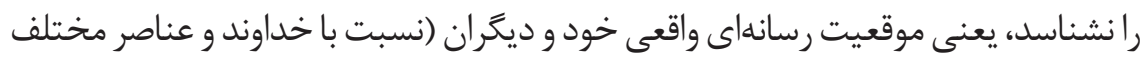


جهان رسـانهاى در محضر حق تعالى) را به درستى درك نكند، به لوازم اين درك ملتزم

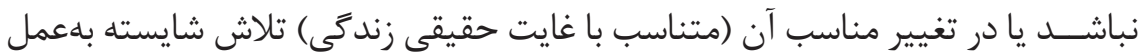

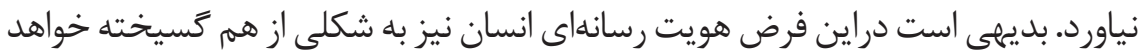
شد. اينك در شرايط يساكرونايى، اهميت اين رويكرد در فضاى رسانهاى دو جندان مى دهود.

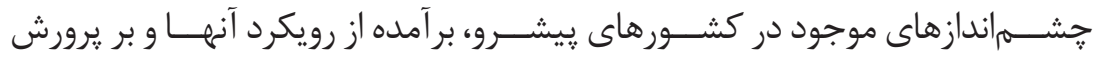
مصرف كننده مقاوم، يرورش تكنســين خلاق و يرورش توليدكننده رسانه تأكيد دارند.

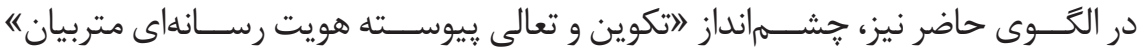

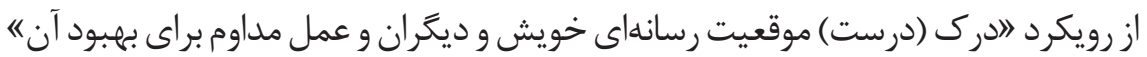

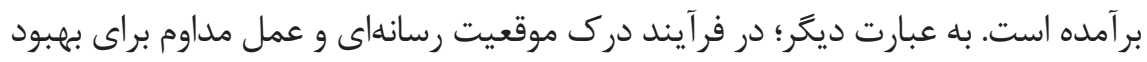

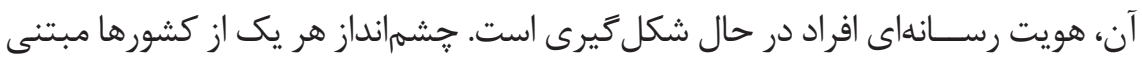

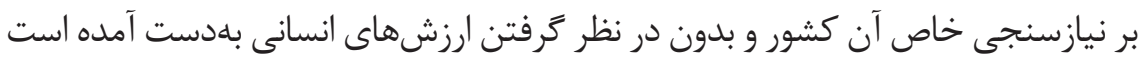

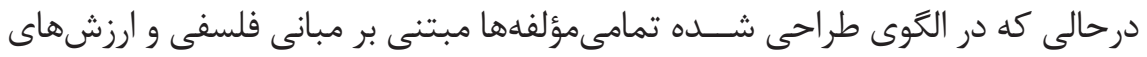

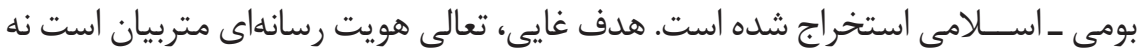

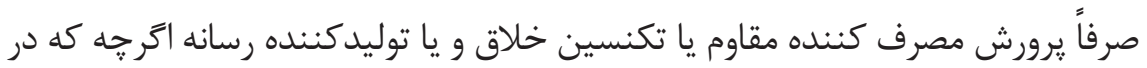

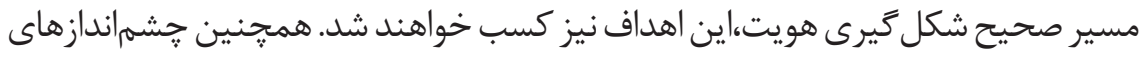

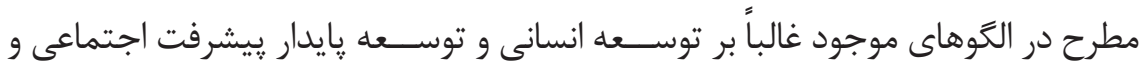

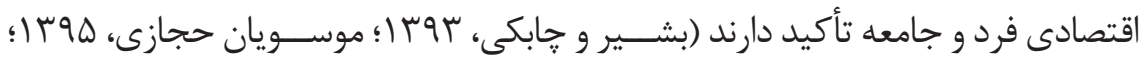

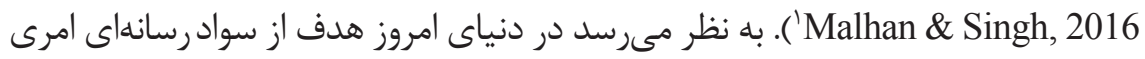

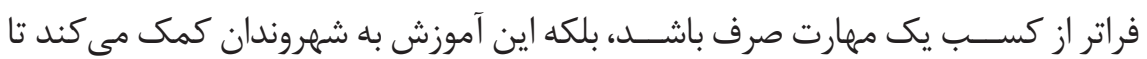

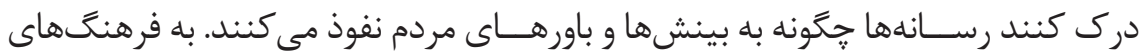

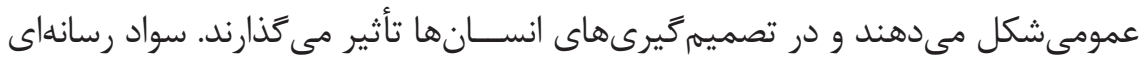

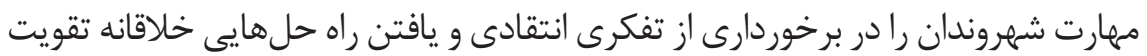

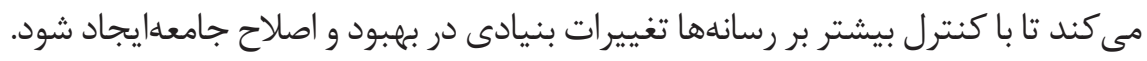

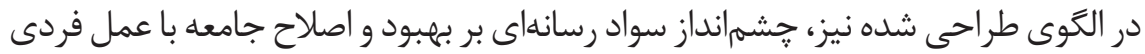

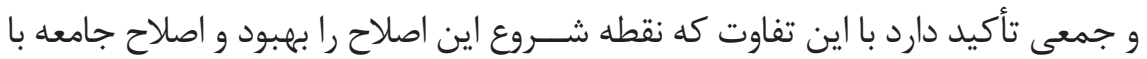

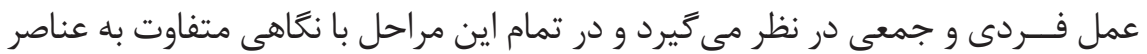


مطالعه تطبيقى وطراحى الكوى مفهومى سواد رسانهاى

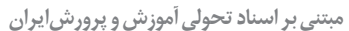

$1 r r-19 f$

زهرانورانى " سيد بشير حسينى اكرم كودرزى "سوسن كشاورز

هستى و روابط مياناين عناصر، در خار جوب نظام معيار اسلامى قدم بر مى دارد. از جمله مهمترين مزيتهاى الكَوى طراحى شـــه، نســــت به يافتههاى تحقيقات

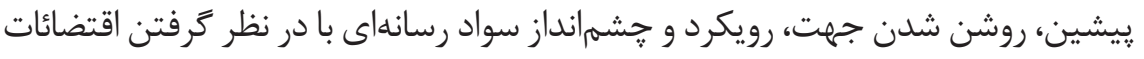

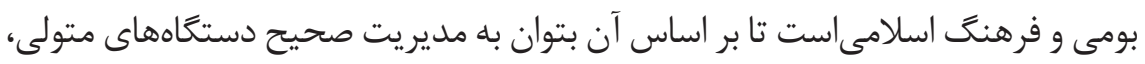

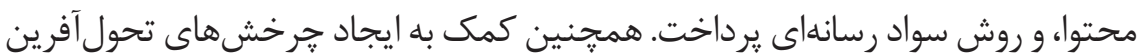

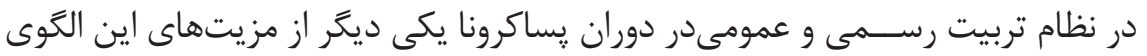

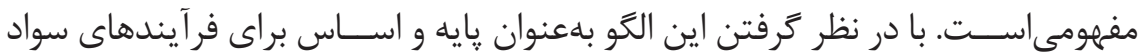

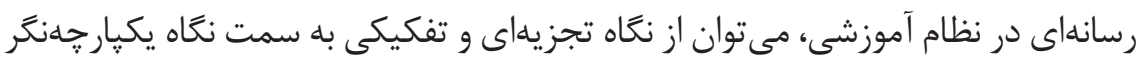

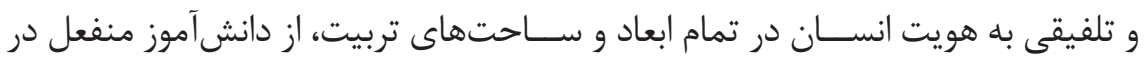

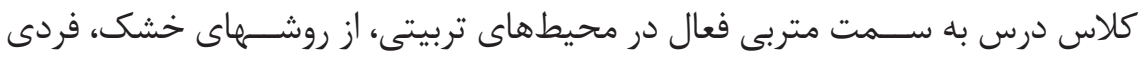

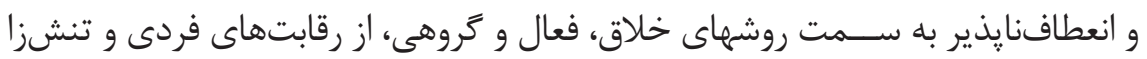

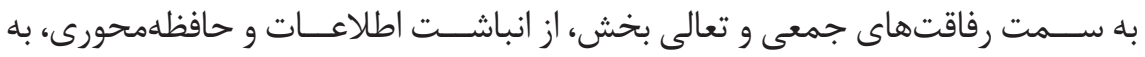

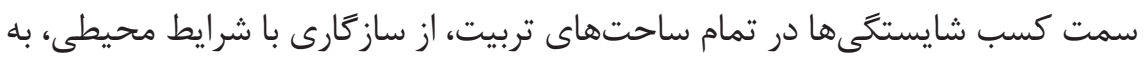

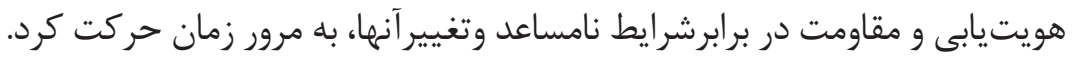

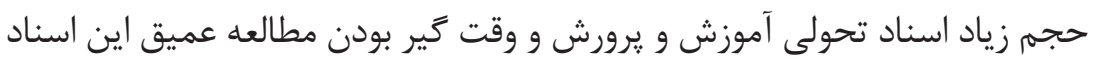

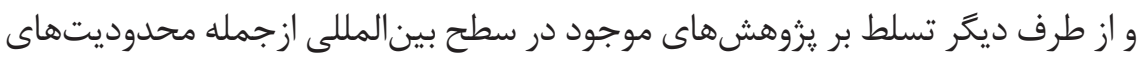

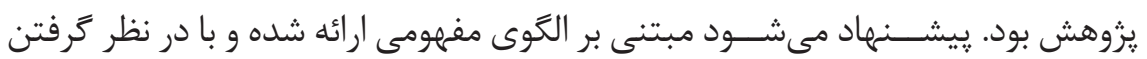

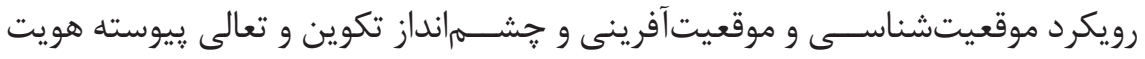

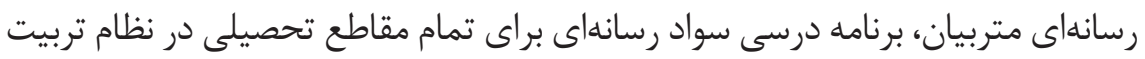

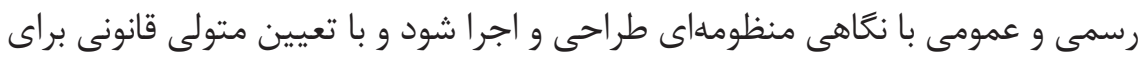

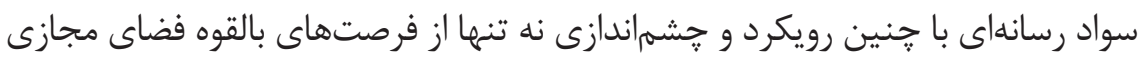

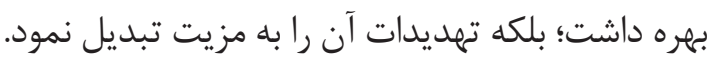

\section{تششكّر و قدردانى تمانى}

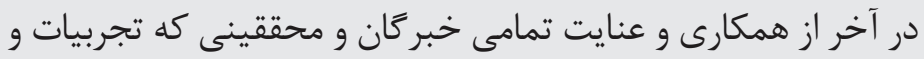

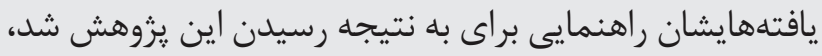
كمال قدردانى و تشكّر را داريمه. 


\section{منابع}

اجاق، سـيده زهرا(YVY I ). آموزش سواد رسانهاى به كودكان: معرفى شاخصهاى محتواى آموزش سواد رسانهاى در دبستان.

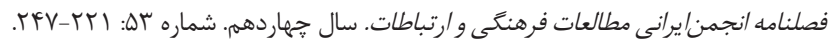

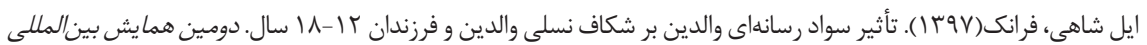

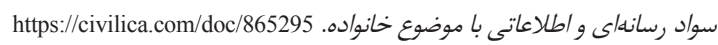

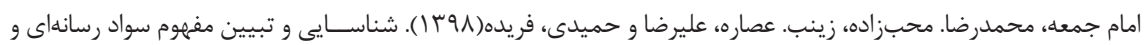

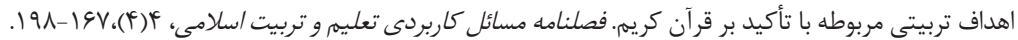

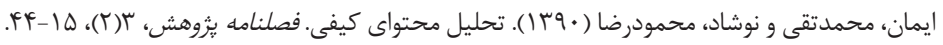

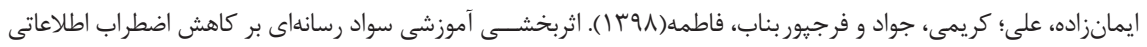

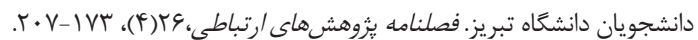

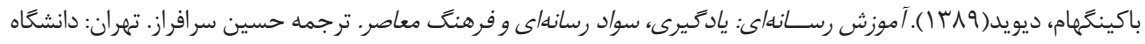
امام صادق(ع).

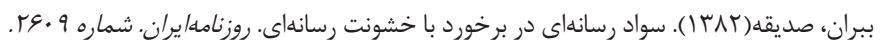

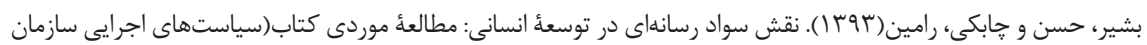

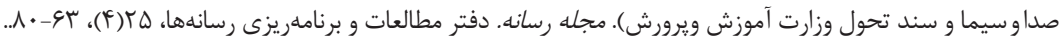

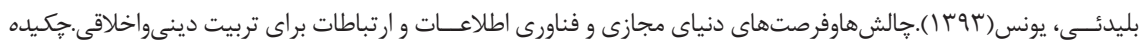

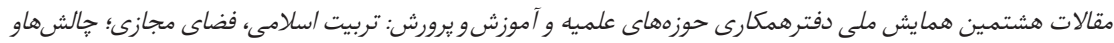

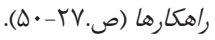

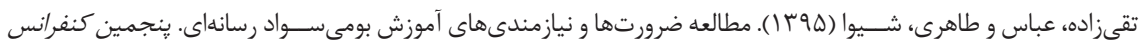

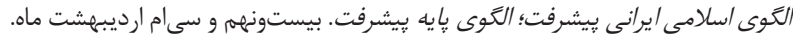

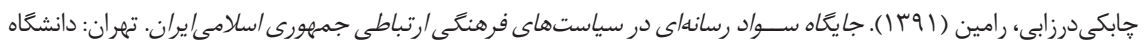
امام صادق(ع).

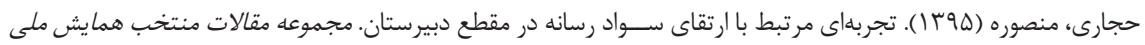

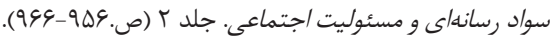

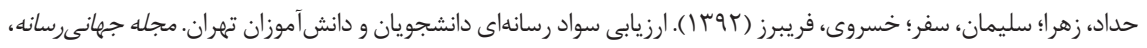

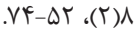

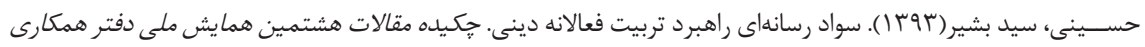

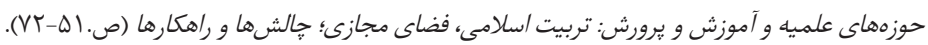

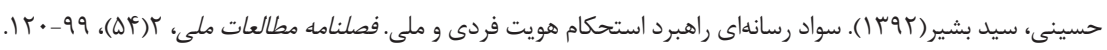

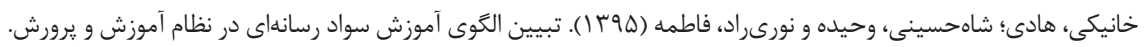

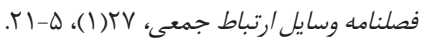

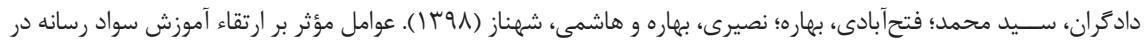

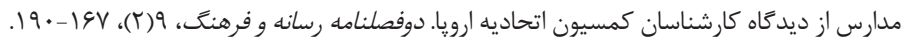

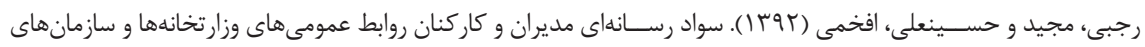

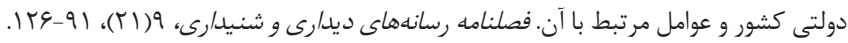

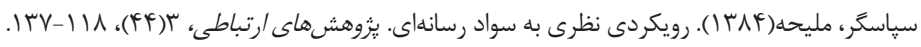

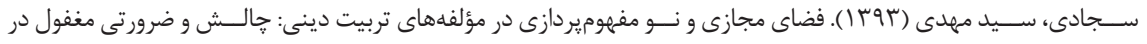

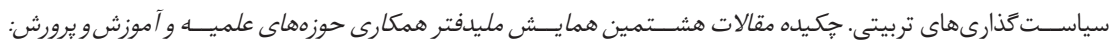

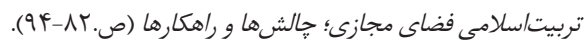

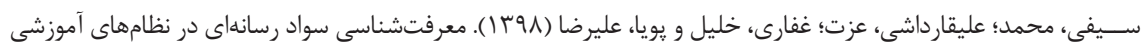

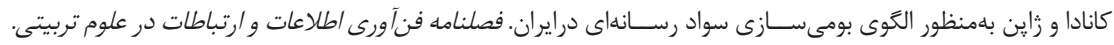
$|r \Delta-11 \Delta,(r)|$.

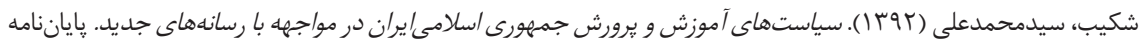


كارشناسى ارشد. دانشكده معارف اسلامى و فرهنَ و ارتباطات. دانشخاه امام صادق(ع).

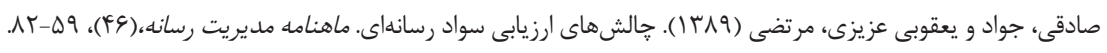

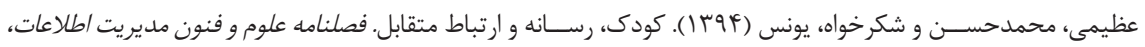
$.94-99$ ، (1))

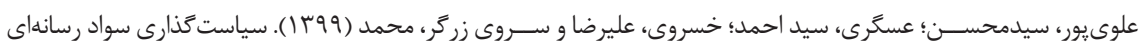

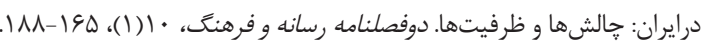

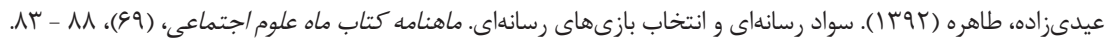

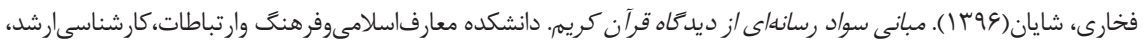

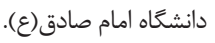

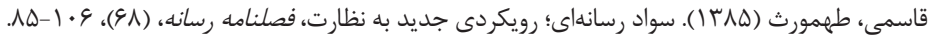

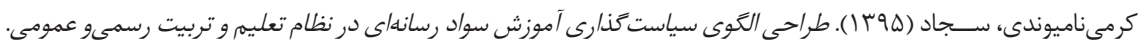

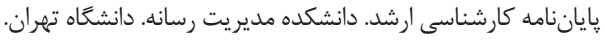

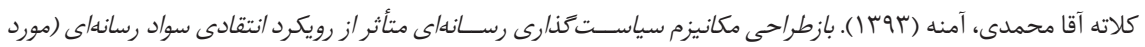

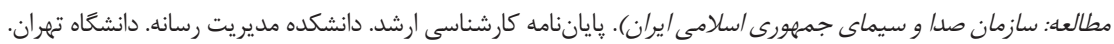

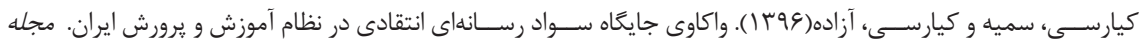

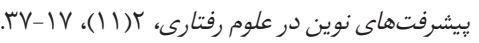

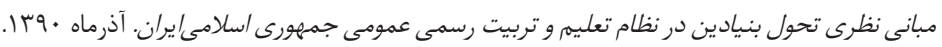
https://ketabnak.com/book/94785

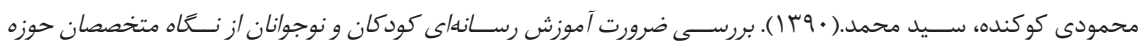

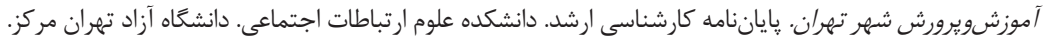

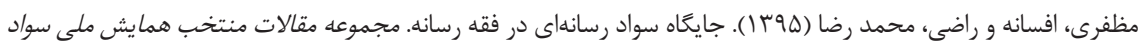

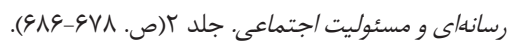

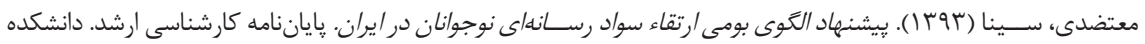
ارتباطات كرايش مديريت رسانه. دانشعاه صدا و سيما.

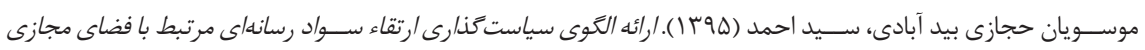

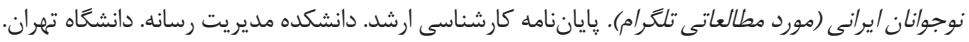

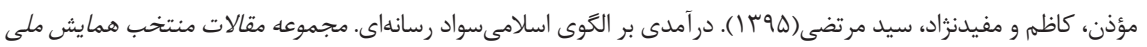

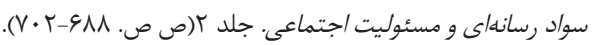

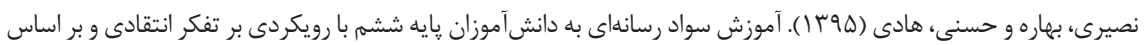

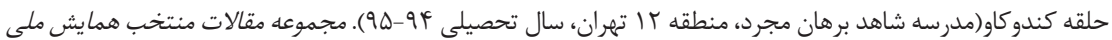

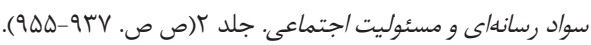

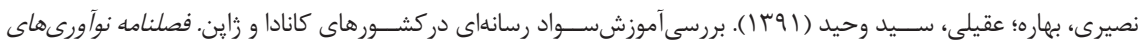

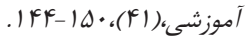

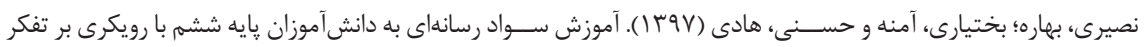

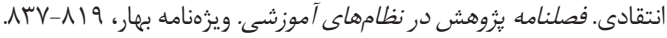

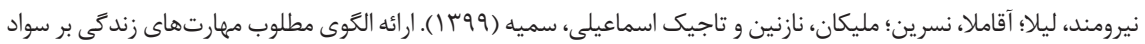

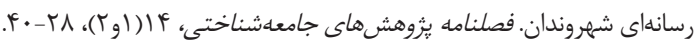

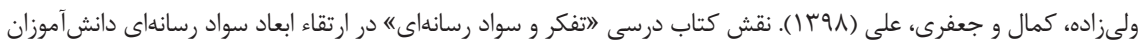

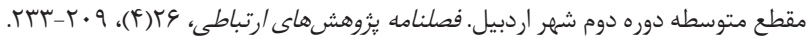


Daunic,Rh.(2011). 10 Years of Media Literacy Education in K-12 Schools. Journal of Media Literacy Education, 3(1), 209-210.

Das, B.(2009). Media education as a Development Project: Connecting Emancipatory Interests and Governance in India. pp. 65-82. In: Mapping media education policies in the world: Visions, Programs, and Challenges, Frau-Meigs, D. Torrent, J.(ed).Published by: The United Nations-Alliance of Civilizations in co-operation with Grupo Comunicar.

Donsbach, W.(2008). The International Encyclopedia of Communication. London: Blackwell publishing.

EUROPEAN COMMISSION, Strengthening media literacy and critical thinking to prevent violent radicalization, Key messages from the PLA, The Hague, 20-22 April 2016, Produced by the ET 2020 Working Groups.

Friedman McDonald, M.(2008). Media literacy in action: Search for education and use of media literacy structures in daily classroom activities. Ph.D. Thesis. University of California.

Hobbs, R.(1998). The Seven Great Debates in th e media literacy Movement.The Journal of Communication, winter,.48(1), 6-32.

Hobbs, R.(2005). Media Literacy and the K-12 Content Areas. Yearbook 104. Malden, MA: Blackwell.

Hobbs,R. Felini,D \& Cappello,G.(2011). Reflections on Global Developments in Media Literacy Education:Bridging Theory and Practice. Journal of Media Literacy Education, 3(2), 66 - 73.

Horton, F. woddy.( 2007). Understandinginformation literacy: A primer. UNESCO: Paris, http://www. uis.unesco.org/Communication/Documents/157020E.pdf.

Livingstone, Sonia., d'Haenens, Leen, Hasebrink, Uwe.(2001), Chilhood in Europe: Contexts for Comparison, pp: 3-31. In: Children and their Changing Media Environment- A European Comparative Study, Livingstone, S. Bovill, M.(eds). Lawrence Erlbaum Associates, Inc.

Malhan, I.V. \& Singh, Jagtar.(2016). Media and Information Literacy Interface for Community Empowerment in India. Media and Information Literacy: Reinforcing Human Rights, Countering Radicalization and Extremism. MILID Yearbook UNESCO, 40-47.

Martens, H.(2010). Evaluating Media Literacy Education: Concepts, Theories and Future Directions. Journal of Media Literacy Education, 2(1), 1-22.

McDougall, J. Berger,R. Fraser, P \& Zezulkova, M.(2015). Media Literacy, Education \&(Civic) Capability: A Transferable Methodology. Journal of Media Literacy Education, 7(1), 4 -17.

Murakami, k.(2016). A Pilot Study of Collaborative Learning and Intercultural Understanding Between Japanese and Chinese Junior High School Students. Media and Information Literacy: Reinforcing Human Rights, Countering Radicalization and Extremism. MILID Yearbook UNESCO, 138-149.

NAMLE.(2020). Media Literacy Defind, National Association for Media Literacy Education, Retrieved March 1, 2020, from: https://namle.net/publications/media-literacy-definitions.

Potter, J.(1908). Media Literacy, Sage Publication.

Schilder, E. Lockee, B \& Saxon, P.(2016). The Challenges of Assessing Media Literacy Education. Journal of Media Literacy Education, 8(1), 32 - 48.

Sebastien Valvocrine, G.(1997). Media literacy education for teens: education coordinator theory on media literacy. Ph.D. Thesis. Marquette University.

Valkenburg, Patti.M.(2000). Media and Youth Consumerism, Journal of Adolescent Health, 27(2). Pp. 52-56.

Valskvi, K.(2005). Research Report Mapping Media Literacy and Education in School. Tokyo: Department of Enviornmental Information Keio University.

Wilson, C. Grizzle, A. Tuazon, A. Akyempong, K. \& Cheung, Ch.(2011). Media and Information Literacy Curriculum for Teachers. Paris:UNESCO.

Wood, E( 2009). Media Literacy Education: Evaluation of Media Literacy Education in Colorado Schools. Master's Thesis The field of mass communication. University of Denver..

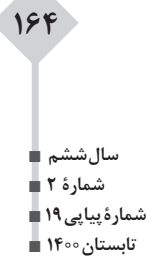

